\title{
An Examination of Self-Regulation and Higher-Order Cognitive Skills as Predictors of Preschool Children's Early Academic Skills
}

\author{
Elif Sezgin ${ }^{1} \&$ Leyla Ulus ${ }^{2}$ \\ ${ }^{1}$ Child Development, Bursa Uludag University, Bursa, Turkey \\ ${ }^{2}$ Preschool Education, Istanbul-Cerrahpasa University, İstanbul, Turkey \\ Correspondence: Elif Sezgin, Child Development, Bursa Uludağ Üniversity, Bursa, Turkey.
}

Received: January 14, $2020 \quad$ Accepted: February 28, $2020 \quad$ Online Published: June 21, 2020

doi:10.5539/ies.v13n7p65

URL: https://doi.org/10.5539/ies.v13n7p65

\begin{abstract}
In this study, the direct and indirect relationships of children's self-regulation skills and their higher-order cognitive skills of cognitive flexibility and abstraction skills with their early academic competencies are examined. Within the scope of the study, the mediating role of self-regulation skills with early academic competencies is investigated. In the study, inhibitory control, behaviour regulation, effortful control and cognitive flexibility are focused on as the main components of executive functions which develop in the early childhood period. The research data were obtained from 185 children aged 60-72 months attending preschool education institutions in the central province of Bursa, and from 16 of these children's teachers. For determining the children's self-regulation skills, effortful control and behaviour regulation were evaluated. Stepwise multiple regression analysis was used to test whether or not the children's self-regulation and higher-order cognitive skills predicted their early academic competencies. As a result of the research, it was determined that the self-regulation skills of effortful control and behaviour regulation predicted early academic skills and attitudes. A statistically significant relationship of cognitive flexibility and abstraction skills with early academic success scale scores was not found. The findings are discussed in terms of the relationship of behaviour regulation and effortful control with early academic success and competencies.
\end{abstract}

Keywords: behaviour regulation, early academic competencies, cognitive flexibility, executive functions

\section{Introduction}

Self-regulation is an individual's planning of his own ideas, emotions and behaviours, and his revision of these with the feedback he receives, in order to achieve personal goals (Zimmerman, 2000). Development of early childhood self-regulation is generally regarded as an early-life determinant of achievements in later life (Montroy, Bowles, Skibbe, McClelland, \& Morrison, 2016). It is known that self-regulation efforts in the preschool period consist of effortful control and executive functions (Zhou, Chen, \& Main, 2012). In the related literature, it is seen that effortful control and executive functions are regarded as interrelated but distinct concepts that reveal cognitive, emotional/motivational and behavioural regulation in children (Bridgett, Oddi, Laake, Murdock, \& Bachmann, 2013; Bryce, Whitebread \& Szücs, 2015). Accordingly, it is known that these two concepts explain different dimensions of self-regulation skills and that these skills contribute to development (Blair \& Razza, 2007; Eisenberg, Valiente \& Eggum, 2010). Executive functions help the individual to understand, monitor and control his reaction to the environment, and, moreover, to solve problems related to his desired behaviour and/outcomes in the future (Montroy et al., 2016). While executive functions are a research subject of cognitive neurology and clinical psychology, effortful control is essentially a concept that has emerged as a result of studies on temperament. Effortful control is a group of temperament-based skills regarded as the basis of self-regulation. Rothbart and Bates (2006) defined effortful control as "executive attention capacity, including the ability to inhibit a dominant response in order to perform a subdominant response, to detect errors and to engage in planning". Effortful control shows its most dramatic development in the preschool period (Kochanska, Murray, Jacques, Koenig, \& Vandegeest, 1996), and continues to grow at a moderate rate in the middle childhood period (Lengua, 2006). Effortful control has 5 subdimensions, namely inhibitory control, attentional focusing, attentional shifting, low intensity pleasure, and perceptual sensitivity. The meanings carried by the subdimensions that form this concept are expressed as follows: inhibitory control is the capacity to suppress inappropriate reactions towards uncertain or new situations or instructions and plan accordingly. Attentional shifting is regarded as the ability to 
shift attention from one object or activity to another. Attentional focusing is conceptualised as disposition towards focusing and maintaining attention on a given task or activity. Low intensity pleasure is the degree of pleasure or satisfaction derived from low intensity stimuli, that is, activities carried out calmly. Perceptual sensitivity is regarded as the degree of perceiving low intensity stimuli coming from one's environment with the five senses (Rothbart, Ahadi, Hershey, \& Fisher, 2001). Effortful control includes the skills of managing the attention voluntarily and activating it in the required way to adapt it, especially when the child does not wish to do a specific thing. For example, the skills of focusing the attention when there are distractions, not interrupting others, and sitting in the theatre or classroom and forcing oneself to perform an unpleasant task are part of effortful control (Posner \& Rothbart, 2007). These skills form the basis of the emergence of self-control, which is an important milestone in a child's development. Effortful control develops rapidly in the preschool years and continues to develop during the early school years (Rothbart \& Bates, 2006). There are big individual differences in effortful control in the first five years of life in almost all children. As is the case for other aspects of temperament, the differences in effortful control are believed to be due both to biological factors (genetic and constitutional factors like prenatal environment), and to environmental effects (such as on antenatal care) and exposure. Effortful control is believed to include executive attention skills and to be associated with activity in the anterior cingulate gyrus and the prefrontal cortex parts of the brain (Posner \& Rothbart, 2007). As part of executive attention, voluntary control of efforts and emotions is revealed to be an effective control for resolving conflicts with inconsistent information, correcting errors and planning new actions (Posner \& Rothbart, 1998; Rothbart \& Bates, 2006). While some researchers from various disciplines have focused on the role of self-regulatory skills/effortful control in children's academic achievements (Kochanska, Murray, \& Harlan, 2000; Valiente, Lemery-Chalfant, \& Swanson, 2010), others have focused on the role of behaviour regulation (Von Suchodoletz, Trommsdorff, Heikamp, Wieber, \& Gollwitzer, 2009). Behaviour regulation, which is included in self-regulation, expresses the emergence of the integration, or collaboration of the attention, working memory and inhibitory control executive functions as behaviour (Wanless, McClelland, Tominey, \& Acock, 2011). Behaviour regulation incorporates the cognitive processes into the wider structure of self-regulation. Cognitively, behaviour regulation is a set of cognitive skills consisting of attention, working memory and inhibitory control, which are known as executive functions (McClelland \& Cameron, 2012; Ursache, Blair, \& Raver, 2012). Moreover, behavioural regulation is an aspect of self-regulation and is defined as the integration of cognitive processes that include attention, working memory and inhibitory control (McClelland, Cameron, Wanless, \& Murray, 2007; Wanless et al., 2011). Since effortful control comprises executive attention (e.g., attentional focusing and shifting) and inhibitory control skills (Eisenberg et al., 1997; Rothbart \& Bates, 2006), behavioural regulation can be an indicator of effortful control.

A component of executive function, cognitive flexibility expresses the ability to switch to different thoughts and actions depending on situational demands. Cognitive flexibility is the process of adapting thoughts and behaviours as a response to situational demands (Geurts, Corbett, \& Solomon, 2009). Cognitive flexibility also expresses the ability to begin to solve a problem in one way and later to solve the same problem in a different way (Dick, 2014). These skills mean the ability to alter response patterns, develop alternative strategies, divide one's attention and process more than one source of information simultaneously (Anderson, 2002). As can be seen, the concept of cognitive flexibility indicates more than one skill. Despite evidence that the basic components of executive function are present in the early childhood period, the development of the effectiveness of these cognitive processes continues in middle childhood and beyond (Davidson, Amso, Anderson \& Diamond, 2006; Dick, 2014). In studies on the subject of the development of executive function, attention is drawn to abstraction together with cognitive flexibility. Abstraction expresses the process by which individual characteristics of objects and the relationships between them are inferred and "experienced on their own". Abstraction is an important skill that enables individuals to find similarities between objects (Gentner \& Lowenstein, 2002), which is very important for generalisation. According to Hampton (2003), abstraction requires the storage of three types of information. These are: (1) information about which dimensions of the situation are relevant (e.g., a key's colour rather than its shape or size); (2) information about the dimensions that reliably predict how we should act (e.g., red or yellow values in the colour dimension); (3) information about the variability of the predictive values (Hampton, 2003). Briefly, abstraction involves not storing anything else or at least distinguishing these pieces of information relevant to the action from the others. Therefore, the more the degree of storage of important or relevant information and the degree of rejection of everything else increase, the more abstract the representation will be. In this way, abstraction allows us to process information rapidly and easily; our attention is not distracted by irrelevant changes in other dimensions. On the other hand, the disadvantage of abstraction is that we fail to notice or record details which may prove to be relevant if the task or situation changes. Therefore, all abstraction involves selectively rejecting some of the information that is presented. In this way, for example, we may form an abstract representation of the concept "TRIANGLE" by selecting the common elements (a closed plane figure with only three straight sides and 
three corners) and ignoring details of the angles or sizes of individual triangles that we may encounter (Hampton, 2003). Development researchers have argued that executive function skills, especially working memory and attentional control, facilitate readiness for academic skills and early learning by supporting behavioural self-regulation capacity and social competence (Blair, 2002; Hughes \& Ensor, 2007). In other words, it can be said that development in executive functions is related to children's academic competences. The concept of academic competence was put forward by DiPerna and Elliott (1999). Based on a primary school study, DiPerna and Elliott (1999) emphasised the academic competence concept to distinguish preschool academic skills and other in-class behaviours that contribute to success in class. Here, in-class behaviours were named "academic enablers" and were associated with academic skills (DiPerna, \& Elliott, 2002; Elliott, DiPerna, Mroch, \& Lang, 2004; DiPerna, 2004). Early academic skills include early literacy, comprehension, arithmetic, and creative and critical thinking skills (DiPerna, 2004; Welsh, Nix, Blair, Bierman, \& Nelson, 2010). Early literacy skills include oral language skills, pronunciation, alphabet knowledge, phonological awareness, vocabulary and writing awareness skills (Storch \& Whitehurst, 2002).

The early childhood period is vitally important for the development of executive functions. When the research is examined, there are findings which state that executive functions are predictors of academic skills both in the preschool period and in later years (Allan, Hume, Allan, Farrington, \& Lonigan, 2014; Blair \& Razza, 2007; Blair, Knipe, Gamson,2008; Blair, 2002). These findings suggest that executive functions need to be supported in the early childhood period. The related literature reveals that the relationship of executive functions with preschool children's early academic skills such as reading, writing or mathematics, or their relationship with social and emotional skills was examined (Espy et al., 2004; Allan, Hume, Allan, Farringto, \& Lonigan, 2014; Blair \& Razza, 2007; Blair, Knipe, Gamson, 2008; Blair, 2002). However, to our knowledge, it can be said that there are few studies dealing separately with the relationship of the components of executive functions, i.e. behaviour regulation, effortful control and cognitive flexibility with preschool children's early academic achievements. In the conducted studies, generally, the relationship of one or two components of executive functions with academic skills is focused on (ex. Blair \& Razza, 2007; Allan, Hume, Allan, Farrington, \& Lonigan, 2014). Moreover, to our knowledge, there are lack of studies and limited findings that investigate the relationship between these components and early academic skills and attitudes at the same time. In this study, we focus on inhibitory control, behaviour regulation, effortful control and cognitive flexibility as the main components of executive functions that develop in the early childhood period. Consequently, in this study, an attempt will be made to examine the degree to which the effortful control and behaviour regulation components of executive functions, and children's higher-order cognitive skills of abstraction skills and cognitive flexibility, predict their early academic skills and early academic attitudes.

\section{Method}

\subsection{Procedure}

In this study, information related to effortful control in children and early academic skills in the early childhood period was obtained from teachers. The two scales used in the research are scales based on teachers' evaluations. Considering that they have experience of working with children in class for a long time, teachers are in a first-class position for identifying and reporting children's strong and weak aspects (Pool \& Hourcade, 2011).

In the study, the data obtained about the children from teachers were processed at the end of the second semester of the 2018-2019 academic year. The data were obtained from 195 children aged 60-72 months attending Preschool Education institutions in the Nilüfer and Osmangazi districts, which are central districts of the Province of Bursa in Turkey, and from 16 of their teachers. To obtain accurate information about each child from teachers, it was important that they were closely acquainted with each of the children in their class. Furthermore, care was taken to select experienced teachers. Each teacher had experience ranging between 10 and 20 years. During measurement of cognitive flexibility, 10 children refused to be assessed on the computer, and so 185 children were included in the analyses.

Since more than one scale was used to collect data from the children related to behaviour regulation and cognitive flexibility, implementation of the measurement tools was made by giving an interval between them.

The Head-Toes-Knees-Shoulders (HTKS) Task Measurement Tool was implemented by the researchers individually for each child in a separate and silent room. Each section of the measurement tool was scored separately for correct behaviours. Every correct response given by a child was recorded on the coding page for each child.

The computer version of the "Flexibility Item Selection Task" test for cognitive flexibility was used. The computer version contains 18 trials. The test was carried out on a laptop computer individually for each child. The responses given by the children were recorded in order for each trial. 
Demographic characteristics of children participating in the study are presented in Table 1.

Table 1. Demographic characteristics of children

\begin{tabular}{ccccc}
\cline { 2 - 4 } & & $\mathrm{N}$ & \multicolumn{2}{c}{$\%$} \\
\cline { 2 - 5 } & Age & 5 & 75 & $40.5 \%$ \\
& & 6 & 110 & $59.5 \%$ \\
& Gender & Female & 85 & $46 \%$ \\
& & Male & 100 & $54 \%$ \\
& Socio-economic status & Low & 44 & $24 \%$ \\
& & Middle & 141 & $76.2 \%$ \\
\hline
\end{tabular}

Note. $\mathrm{n}: 185$.

Examination of Table 1 reveals that the majority of the children participating in the study were aged $6(59 \%)$, that $54 \%$ were male and $46 \%$ were female, and that most of them had middle socio-economic status (79\%). The study was carried out in state schools in areas inhabited by families with low and middle socio-economic levels.

\subsection{Data Collection Tools}

To determine children's levels of effortful control, the "Effortful Control Scale" (ECS), which was developed by Rothbart, Ahadi, Hershey, and Fisher (2001) and whose Turkish validity and reliability study was conducted by Adagideli, Ural, and Polat (2019), was used. The short version of the parents' form of this scale had previously been adapted to Turkish (Akın-Sarı, 2009). However, in the meta-analysis study made by Allan et al. (2014), it was concluded that teachers made more accurate assessments of children's effortful control than parents did. Therefore, the need arose for the teachers' version of the scale to be adapted to Turkish, and so the validity and reliability study of the scale and its adaptation to Turkish were performed by Adagideli, Ural, and Polat (2019). The researchers determined an internal consistency coefficient of.94 for the "Effortful Control Scale". The internal consistency coefficients of the subscales of the scale ranged between.75 and.91. Moreover, as a result of the test-retest analyses, a highly statistically significant positive relationship was found between the applications made. Therefore, it was revealed that this scale is a valid and reliable scale that can be used for determining children's effortful control in the preschool period in Turkey. Accordingly, to determine the levels of children's effortful control, the "Effortful Control Scale" was used in this study, based on teachers' observations.

To determine children's behaviour regulation skills, the "Head-Toes-Knees-Shoulders" (HTKS) Task Measurement Tool, which was developed by Ponitz et al. (2009) and whose Turkish validity and reliability study was carried out by Sezgin and Demiriz (2015), was used. This measurement tool has strong reliability (Ponitz et al., 2009; Matthews, Marulis, \& Williford, 2014; Montroy, Bowles, Skibbe, \& Foster, 2014; Yalçıntaş-Sezgin, Ulus, \& Şahin, 2019; Wanless et al., 2011). It is an easy-to-use self-regulation measurement tool. For the Turkish form, adapted to Turkish by Sezgin and Demiriz (2015), the Cronbach's alpha values of the "Head-Toes-Knees-Shoulders" (HTKS) task measurement tool were found to be 0.93 for Section 1, 0.95 for Section 2, 0.94 for Section 3 and 0.96 for the whole scale (Sezgin \& Demiriz, 2015). The measurement tool consists of three sections. It contains a total of 30 tasks, with 10 tasks for each section. These tasks measure children's attention, working memory and inhibitory control skills and their ability to generate behaviour during social interaction at the same time. In a task, children are expected to give a behavioural response to four different verbal instructions, and these responses are observed and recorded. A short training session is required in order to apply the measurement tool, but it does not require special equipment and is based on interaction between the application, implementer and child (Sezgin \& Demiriz, 2015). There are tasks in the measurement tool that children are expected to comply with. In these tasks, the child is required to obey certain rules for touching parts of their body in the opposite way to what the teacher says. These tasks are based on the child's ability to apply working memory, flexible attention and inhibitory control, which are the central components of behavioural regulation. To continue a task successfully, a child must pay attention to the instructions, remember the instructions throughout the test, avoid responding instinctively to his own impulses and respond in the opposite way, and alter his attention in a flexible way when the rules are changed. The instructions become more difficult as the task progresses. In the first section, the children are instructed to touch their heads and toes in the opposite way to what is said. They are asked to continue to do the exact opposite throughout the test. In the second section, the knees and shoulders are added. In the third section, the rules are changed by pairing the head and knees, and the shoulders and toes. There are 10 items in each section, each scored as follows: 0 for incorrect, 1 for self-correct and 2 for correct. 
In this way, a child can obtain a maximum score of 20 in each section and a total of 60 in the whole test.

To determine the children's higher-order cognitive skills of flexibility and abstraction, the "Flexible Item Selection Task" (FIST) test, which was developed by Jacques and Zelazo (2001), and whose validity and reliability study for Turkish was conducted by Şahin and Arı (2017), was used. For determining the reliability of the test in the study, the internal consistency of the test items and the test-retest correlation were examined. To determine internal consistency, Cronbach's alpha reliability analysis was made, and for test-retest reliability, the Pearson Moments Product Correlation Coefficient was calculated. The Cronbach's alpha coefficients calculated for reliability of the test were determined as $(\alpha) 0.81$ for the abstraction skills and $(\alpha) 0.86$ for the cognitive flexibility subdimensions. The correlation coefficients related to test-retest reliability were determined as 0.89 for abstraction skills and 0.90 for cognitive flexibility (Şahin \& Arl, 2017). These findings reveal that this is a valid and reliable tool for evaluating executive functions of children aged 60-71 months in Turkey. The Flexible Item Selection Task consists of 2 subdimensions, namely "abstraction skills" and "cognitive flexibility", and 30 items. In this study, the computer version of the FIST was used. The computer version includes 18 trials. In each trial, participants are shown three items seen in different windows. The items consist of three-dimensional combinations: colour, shape and size. Colour is represented by blue, red and yellow, shape by a boat, shoe and teapot, and size by small, medium and large. All children are given three tasks, always presented in the same order. These are: object recognition task, favourite items task, and flexible item selection task, respectively.

Object recognition task: The aim of this task is to determine whether or not children correctly identify all objects of every size used in the flexibility task when selecting objects. Favourite items task: This consists of a demonstration trial and three practice trials. The aim of this task is to teach children how to choose two objects on the screen. Flexible item selection task: This consists of a demonstration trial, two practice trials and 15 test trials. Each trial includes Selection 1 and Selection 2. In Selection 1, participants are asked to select 2 objects that are similar in one aspect. In Selection 2, participants are asked to select 2 objects that are similar to each other in another way. In Selection 1, abstraction skills are measured, while in Selection 2, cognitive flexibility is evaluated. Scoring: in each trial, participants who make a match correctly at the first attempt are given one point for the first matching. In the event that their first matches are correct, participants also receive one point for the second matching if they complete the other possible pair correctly. This scoring system is accepted because an incorrect matching made in the first trial means that the other matching will inevitably be correct. Scoring the second matching as correct when the first matching is wrong results in high (exaggerated) scores for the second matching. Scores obtained from the first matching, in which abstraction skills are assessed, and from the second matching which measures cognitive flexibility, that is, scores obtained from the first and second matchings, are analysed separately (Campbell, Landry, Russo, Flores, Jacques \& Burack, 2013). In total, maximum scores of 15 can be obtained for abstraction skills and 15 can be obtained for cognitive flexibility.

To determine early academic skills, the Teacher Rating Scale of Early Academic Competence (TRS-EAC), which was developed by Reid, DiPerna, Missall, and Volpe (2014), and whose Turkish reliability and validity study was conducted by Şenol and Turan (2019), was used. Following the reliability study of the scale carried out in the USA, Cronbach's alpha internal consistency coefficients ranged from.89 to.98 (Reid, DiPerna, Missal, \& Volpe, 2014). As a result of the reliability study conducted for adapting the scale for Turkish children, Cronbach's alpha internal consistency coefficients of the Early Academic Competence Scale were seen to range between.94 and.98 (Şenol \& Turan 2019). Based on these values, it can be said that this measurement tool has strong reliability for use in Turkey. Consisting of 85 items, the TRS-EAC was developed to measure early academic competence in children aged 36-72 months and consists of a combination of the Early Academic Skills (38 items) and Early Academic Enablers (47 items) Scales. The Early Academic Skills Scale includes the subdimensions of creative thinking, critical thinking, numeracy, early literacy and comprehension skills, while the Early Academic Enablers Scale includes the subdimensions of approaches to learning, social and emotional competence, fine motor skills, gross motor skills and communication skills.

\subsection{Data Analysis}

Shapiro-Wilk's test was used to examine whether or not the data showed normal distribution. Relationships between variables were examined with the Pearson correlation coefficient. For modelling the relationship between executive functions and early academic skills, stepwise multiple regression analysis was performed. The significance level was determined as $\alpha=0.05$. Statistical analysis of the data was made with the SPSS 23.0 statistical software program (IBM Corp. Released 2015. IBM SPSS Statistics for Windows, Version 23.0. Armonk, NY: IBM Corp.) 


\section{Findings}

Table 2. Mean scale scores of children's early academic skills scale and early academic competences, self-regulation skills and higher-order cognitive skills

\begin{tabular}{cccccc}
\hline & & Mean & Standard deviation & Minimum & Maximum \\
\hline & Creative Thinking & 24.10 & 2.57 & 16.00 & 32.00 \\
Early Academic Skills Scale & Critical Thinking & 29.37 & 2.56 & 21.00 & 38.00 \\
& Numeracy & 15.29 & 1.53 & 7.00 & 24.00 \\
& Early Literacy & 13.48 & 2.56 & 5.00 & 23.00 \\
& Comprehension Skills & 21.18 & 1.58 & 16.00 & 30.00 \\
& Approaches to Learning & 44.38 & 3.30 & 32.00 & 57.00 \\
& Social and Emotional Competence & 35.58 & 2.83 & 27.00 & 47.00 \\
Early Academic Enablers Scale & Fine Motor Skills & 18.40 & 1.97 & 14.00 & 30.00 \\
& Gross Motor Skills & 9.00 & .53 & 4.00 & 11.00 \\
& Communication Skills & 30.20 & 3.32 & 18.00 & 42.00 \\
& Inhibitory Control & 56.13 & 5.07 & 41.00 & 72.00 \\
Effortful Control Scale & Attentional Focusing & 41.67 & 5.66 & 26.00 & 56.00 \\
& Attentional Shifting & 21.76 & 3.49 & 11.00 & 30.00 \\
& Perceptual Sensitivity & 54.34 & 7.99 & 25.00 & 71.00 \\
& Low Intensity Pleasure & 55.73 & 7.68 & 31.00 & 74.00 \\
Behaviour Regulation HTKS Score & & 41.63 & 13.79 & 0.00 & 60.00 \\
Selection 1(abstraction skills) Total & & 12.77 & 3.67 & 0.00 & 15.00 \\
Selection 2 (cognitive flexibility)Total & & 11.49 & 3.56 & 1.00 & 15.00 \\
\hline
\end{tabular}

Table 3. Exploratory analysis results for correlation among children's early academic skills and early academic enablers, self-regulation skills and higher-order cognitive skills

\begin{tabular}{|c|c|c|c|c|c|c|c|c|c|c|c|c|c|c|c|c|c|}
\hline & 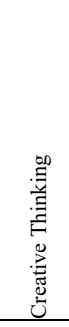 & 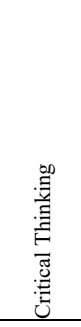 & $\begin{array}{l}\text { 总 } \\
\text { 号 } \\
\text { 言 }\end{array}$ & 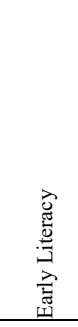 & 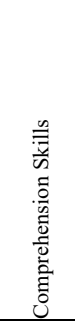 & 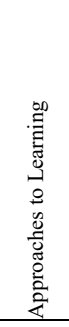 & 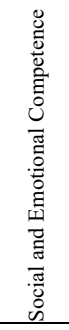 & 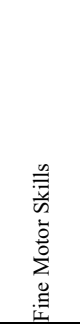 & 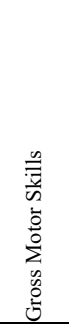 & 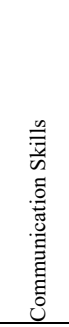 & 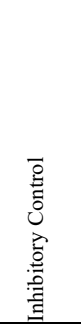 & 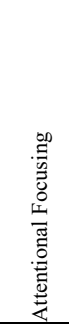 & 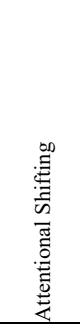 & 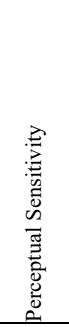 & 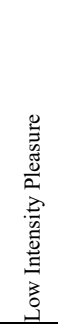 & 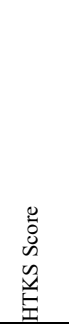 & 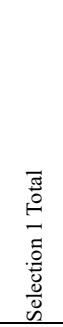 \\
\hline Critical Thinking & $.553^{* * *}$ & & & & & & & & & & & & & & & & \\
\hline Numeracy & $.410^{* *}$ & $.542^{* *}$ & & & & & & & & & & & & & & & \\
\hline Early Literacy & $.427^{* * *}$ & $.576^{* *}$ & $.313^{* *}$ & & & & & & & & & & & & & & \\
\hline Comprehension Skills & $.524^{* *}$ & $.607^{* *}$ & $.643^{* *}$ & $.368^{* *}$ & & & & & & & & & & & & & \\
\hline Approaches to Learning & $.593^{* *}$ & $.418^{* *}$ & $.314^{* *}$ & $.408^{* *}$ & $.373^{* * *}$ & & & & & & & & & & & & \\
\hline $\begin{array}{l}\text { Social and Emotional } \\
\text { Competence }\end{array}$ & $.415^{* *}$ & $.230^{* * *}$ & $.178^{*}$ & $.326^{* *}$ & $.321^{* *}$ & $.603^{* *}$ & & & & & & & & & & & \\
\hline Fine Motor Skills & $.471^{* *}$ & $.545^{* *}$ & $.526^{* *}$ & $.424^{* *}$ & $.656^{* *}$ & $.517^{* *}$ & $.412^{* *}$ & & & & & & & & & & \\
\hline Gross Motor Skills & .095 & .112 & .127 & .028 & .103 & $.221^{* * *}$ & .018 & $.244^{* *}$ & & & & & & & & & \\
\hline Communication Skills & $.632^{* *}$ & $.545^{* *}$ & $.370^{* *}$ & $.386^{* *}$ & $.470^{* *}$ & $.479^{* * *}$ & $.497^{* *}$ & $.502^{* *}$ & $.179^{*}$ & & & & & & & & \\
\hline Inhibitory Control & .064 & -.022 & -.051 & .028 & -.072 & $.246^{* *}$ & $.307^{* *}$ & .014 & .026 & .105 & & & & & & & \\
\hline Attentional Focusing & $.234^{* * *}$ & $.266^{* *}$ & .121 & $.178^{*}$ & .113 & $.387^{* *}$ & $.313^{* * *}$ & $.191^{* *}$ & -.002 & $.290^{* *}$ & $.386^{* *}$ & & & & & & \\
\hline Attentional Shifting & $.175^{*}$ & 0.032 & 0.105 & 0.082 & 0.032 & $.283^{* *}$ & $.276^{* *}$ & 0.091 & $.155^{*}$ & $.182^{*}$ & $.425^{* * *}$ & $.195^{* *}$ & & & & & \\
\hline Perceptual Sensitivity & $.372^{* * *}$ & $.289^{* * *}$ & .118 & $.269^{* *}$ & $.198^{* * *}$ & $.372^{* *}$ & $.277^{* *}$ & $.223^{* *}$ & .087 & $.385^{* *}$ & $.199^{* *}$ & .086 & $.277^{* *}$ & & & & \\
\hline Low Intensity Pleasure & .093 & $.208^{* * *}$ & .119 & .104 & $.231^{* *}$ & $.230^{* * *}$ & $.239^{* *}$ & $.187^{\circ}$ & .045 & $.199^{* *}$ & $.180^{*}$ & $.222^{* *}$ & $.156^{*}$ & $.335^{* *}$ & & & \\
\hline HTKS Score & $.351^{* *}$ & $.341^{* *}$ & $.312^{* *}$ & $.431^{* *}$ & $.336^{* *}$ & $.420^{* *}$ & $.401^{* *}$ & $.369^{* *}$ & .080 & $.420^{* *}$ & $.255^{* * *}$ & .062 & -.094 & $.237^{* *}$ & .065 & & \\
\hline Selection 1 Total & $.337^{* *}$ & $.288^{* * *}$ & $.305^{* *}$ & $.341^{* *}$ & $.313^{* * *}$ & $.406^{* *}$ & $.394^{* * *}$ & $.318^{* *}$ & .045 & $.393^{* *}$ & $.281^{* * *}$ & .007 & -.052 & $.251^{* *}$ & .075 & $.749^{* * *}$ & \\
\hline Selection 2 Total & $.315^{* *}$ & $.272^{* * *}$ & $.251^{* *}$ & $.279^{* *}$ & $.305^{* *}$ & $.392^{* * *}$ & $.287^{* *}$ & $.283^{* *}$ & .069 & $.305^{* *}$ & $.285^{* * *}$ & .008 & -.071 & $.256^{* *}$ & .097 & $.629^{* * *}$ & $.716^{* *}$ \\
\hline
\end{tabular}


When the relationships between the Early Academic Skills and those of the Early Academic Enablers in Table 3 are examined, a moderate positive relationship of approaches to learning, social and emotional competence, and fine motor skills with creative thinking is revealed $(\mathrm{r}=0.593, \mathrm{p}<0.01 ; \mathrm{r}=0.415, \mathrm{p}<0.01 ; \mathrm{r}=0.471, \mathrm{p}<0.01$, respectively). There is a strong positive relationship between communication skills and creative thinking $(\mathrm{r}=0.632$, $\mathrm{p}<0.01)$. A moderate positive relationship of approaches to learning, fine motor skills and communication skills with critical thinking is revealed ( $\mathrm{r}=0.418, \mathrm{p}<0.01 ; \mathrm{r}=0.545, \mathrm{p}<0.01 ; \mathrm{r}=0.545, \mathrm{p}<0.01$, respectively). There is a weak positive relationship between social and emotional competence and critical thinking $(\mathrm{r}=0.230 \mathrm{p}<0.01)$. A moderate positive relationship can be seen between fine motor skills and numeracy $(r=0.526 \mathrm{p}<0.01)$, while there is a weak positive relationship of approaches to learning, social and emotional competence and communication skills with numeracy $(r=0.314, p<0.01 ; r=0.178, p<0.01 ; r=0.370, p<0.01$, respectively). A moderate positive relationship of approaches to learning, social and emotional competence, fine motor skills and communication skills with early literacy is revealed. While there is a weak positive relationship of approaches to learning and social and emotional competence with comprehension skills, there is a strong positive relationship between fine motor skills and comprehension skills, and a moderate positive relationship between communication skills and comprehension skills.

Examination of the relationships between the between the Effortful Control and those of the Early Academic Skills shows a weak positive relationship of inhibitory control, attentional shifting and perceptual sensitivity with creative thinking. A weak positive relationship of attentional focusing, attentional shifting, perceptual sensitivity and low intensity pleasure with critical thinking is revealed. There is a weak positive relationship between perceptual sensitivity and numeracy. A weak positive relationship can be seen for attentional focusing and perceptual sensitivity with early literacy. A weak positive relationship of attentional shifting, perceptual sensitivity and low intensity pleasure with comprehension skills is revealed.

When the relationships between the subdimensions of the Effortful Control Scale and those of the Early Academic Enablers are examined, there is a weak positive relationship of inhibitory control, attentional focusing, attentional shifting, perceptual sensitivity and low intensity pleasure with approaches to learning $(r=0.246, p<0.01 ; r=0.387$, $\mathrm{p}<0.01 ; \mathrm{r}=0.283, \mathrm{p}<0.01 ; \mathrm{r}=0.372, \mathrm{p}<0.01 ; \mathrm{r}=0.230, \mathrm{p}<0.01$, respectively), and a weak positive relationship of inhibitory control, attentional focusing, attentional shifting, perceptual sensitivity and low intensity pleasure with social and emotional competence ( $\mathrm{r}=0.307, \mathrm{p}<0.01 ; \mathrm{r}=0.313, \mathrm{p}<0.01 ; \mathrm{r}=0.276, \mathrm{p}<0.01 ; \mathrm{r}=0.277, \mathrm{p}<0.01 ; \mathrm{r}=0.239$, $\mathrm{p}<0.01$, respectively). A weak positive relationship can be seen for attentional focusing, perceptual sensitivity and low intensity pleasure with fine motor skills $(r=0.191 \mathrm{p}<0.01 ; \mathrm{r}=0.223 \mathrm{p}<0.01 ; \mathrm{r}=0.187 \mathrm{p}<0.01$, respectively). There is a weak positive relationship between attentional shifting and gross motor skills $(\mathrm{r}=0.155)$. A weak positive relationship of attentional focusing, attentional shifting, perceptual sensitivity, and low intensity pleasure with communication skills is revealed $(\mathrm{r}=0.290, \mathrm{p}<0.01 ; \mathrm{r}=0.182, \mathrm{p}<0.01 ; \mathrm{r}=0.385, \mathrm{p}<0.01 ; \mathrm{r}=0.199, \mathrm{p}<0.01$, respectively).

Examining the relationships between the HTKS-Behavior regulation scores and subdimensions of the Early Academic skills Scale, a weak positive relationship of HTKS scores with creative thinking, critical thinking, numeracy and comprehension skills is revealed(r=0.351, $\mathrm{p}<0.01 ; \mathrm{r}=0.341, \mathrm{p}<0.01 ; \mathrm{r}=0.312, \mathrm{p}<0.01 ; \mathrm{r}=0.336$, $\mathrm{p}<0.01$, respectively). There is a moderate positive relationship between HTKS scores and early literacy $(\mathrm{r}=0.431$, $\mathrm{p}<0.01)$.

When the relationships between HTKS scores and subdimensions of the Early Academic Enablers Scale are examined, it can be seen that there is a moderate positive relationship of HTKS scores with approaches to learning, social and emotional competence and communication skills $(\mathrm{r}=0.420, \mathrm{p}<0.01 ; \mathrm{r}=0.401, \mathrm{p}<0.01 ; \mathrm{r}=0.420, \mathrm{p}<0.01$, respectively). There is a weak positive relationship between HTKS scores and fine motor skills $(r=0.369, p<0.01)$.

Examining the relationships between abstraction skills (with Selection 1) and the Early Academic skills there is a weak positive relationship of abstraction skills with creative thinking, critical thinking, numeracy, early literacy and comprehension skills $(\mathrm{r}=0.337, \mathrm{p}<0.01 ; \mathrm{r}=0.288, \mathrm{p}<0.01 ; \mathrm{r}=0.305, \mathrm{p}<0.01 ; \mathrm{r}=0.341, \mathrm{p}<0.01 ; \mathrm{r}=0.313, \mathrm{p}<0.01$, respectively).

When the relationships between abstraction skills (with Selection 1) and the Early Academic Enablers are examined, a moderate positive relationship is found between abstraction skills and approaches to learning $(\mathrm{r}=0.406, \mathrm{p}<0.01)$. There is a weak positive relationship for abstraction skills with social and emotional competence, fine motor skills and communication skills $(r=0.394, p<0.01 ; r=0.318, p<0.01 ; r=0.393, p<0.01$, respectively).

Examining the relationships between cognitive flexibility (with Selection 2) and the subdimensions of the Early Academic skills Scale, a weak positive relationship of cognitive flexibility with creative thinking, critical thinking, 
numeracy, early literacy and comprehension skills is revealed ( $r=0.315, \mathrm{p}<0.01 ; \mathrm{r}=0.272, \mathrm{p}<0.01 ; \mathrm{r}=0.251, \mathrm{p}<0.01$; $\mathrm{r}=0.279, \mathrm{p}<0.01 ; \mathrm{r}=0.305, \mathrm{p}<0.01$, respectively).

When the relationships between cognitive flexibility (with Selection 2) and the Early Academic Enablers are examined, a weak positive relationship of cognitive flexibility with approaches to learning, social and emotional competence, fine motor skills and communication skills can be seen $(\mathrm{r}=0.392, \mathrm{p}<0.01 ; \mathrm{r}=0.287, \mathrm{p}<0.01 ; \mathrm{r}=0.283$, $\mathrm{p}<0.01 ; \mathrm{r}=0.305, \mathrm{p}<0.01$, respectively).

Table 4. Analysis results for predictive relationships among children's early academic skills and early academic enablers, self-regulation skills and higher-order cognitive skills

\begin{tabular}{ccccccc}
\hline & & Creative Thinking & Critical Thinking & Numeracy & Early Literacy & \multicolumn{2}{c}{ Compre-hension Skills } \\
& & $\mathrm{B}$ & $\beta$ & $\beta$ & $\beta$ & - \\
\hline \multirow{4}{*}{ ECS } & Inhibitory Control & - & -.082 & - & - & - \\
& Attentional Focusing & - & .109 & - & - & - \\
& Attentional Shifting & - & - & - & - & - \\
& Perceptual Sensitivity & .103 & .075 & - & .047 & -039 \\
\multicolumn{1}{c}{ Low Intensity Pleasure } & - & - & - & - & .035 \\
HTKS -Behaviour Regulation & .041 & .037 & .035 & .067 & - \\
Abstraction skills(Selection 1) & - & - & - & - & - \\
Cognitive flexibility(Selection 2 & - & - & - & - & .142 \\
$\mathrm{R}^{2}$ & .198 & .194 & .103 & .190 & 14.179 \\
$\mathrm{~F}$ & 21.087 & 10.166 & 19.744 & 20.081 & $<.001$ \\
\hline
\end{tabular}

While the perceptual sensitivity of the Effortful Control and the Behaviour regulation positively predicted the creative thinking of the Early Academic skills the other scale scores were not found to be statistically significant (Table 4). When perceptual sensitivity and Behaviour regulation increased, creative thinking also increased.

While the attentional focusing and perceptual sensitivity of the Effortful Control and the Behavior regulation positively predicted the critical thinking of the Early Academic skills, the other scale scores were found to be statistically insignificant. While an increase in attentional focusing, perceptual sensitivity and Behavior regulation caused critical thinking to increase, an increase in inhibitory control resulted in a decrease in critical thinking.

The perceptual sensitivity of the Effortful Control positively predicted the early literacy of the Early Academic skills e when perceptual sensitivity increased, early literacy skills also increased.

The low intensity pleasure of the Effortful Control positively predicted the comprehension skills of the Early Academic skills. An increase in low intensity pleasure also caused an increase in comprehension skills.

The Behavior regulation positively predicted the numeracy, early literacy and comprehension skills of the Early Academic Competence When Behavior regulation increased, numeracy, early literacy and comprehension skills also increased.

A statistically significant correlation of abstraction skills and cognitive flexibility with Early Academic skills was not found. 
Table 5. Analysis results for predictive relationships among children's early academic enablers, self-regulation skills and higher-order cognitive skills

\begin{tabular}{|c|c|c|c|c|c|}
\hline & $\begin{array}{c}\text { Approaches to } \\
\text { Learning } \\
\beta\end{array}$ & $\begin{array}{l}\text { Social and Emotional } \\
\text { Competence } \beta\end{array}$ & $\begin{array}{c}\text { Fine Motor } \\
\text { Skills } \\
\beta\end{array}$ & $\begin{array}{l}\text { Gross Motor } \\
\text { Skills } \\
\text { B }\end{array}$ & $\begin{array}{c}\text { Communication } \\
\text { Skills } \\
\text { B }\end{array}$ \\
\hline Inhibitory Control & & .133 & - & - & - \\
\hline Attentional Focusing & .160 & - & - & - & .081 \\
\hline ECS Attentional Shifting & - & - & - & .026 & \\
\hline Perceptual Sensitivity & .117 & - & - & - & .127 \\
\hline Low Intensity Pleasure & - & .055 & - & - & - \\
\hline HTKS -Behabiour Regulation & - & .077 & .052 & - & .065 \\
\hline Abstraction skills(Selection 1) & .200 & - & - & - & - \\
\hline $\begin{array}{l}\text { Cognitive flexibility(Selection } \\
\text { 2) }\end{array}$ & - & - & - & - & - \\
\hline $\mathrm{R}^{2}$ & .305 & .249 & .159 & .026 & .269 \\
\hline $\mathrm{F}$ & 24.720 & 18.763 & 32.629 & 4.614 & 34.862 \\
\hline $\mathrm{P}$ & $<.001$ & $<.001$ & $<.001$ & .033 & $<.001$ \\
\hline
\end{tabular}

Although the inhibitory control of the Effortful Control positively predicted the social and emotional competence of the Early Academic Enablers, no statistical significance could be found with the other of the Early Academic Enablers. As inhibitory control increased, social and emotional competence also increased.

The attentional focusing of the Effortful Control positively predicted the approaches to learning and communication skills subdimensions of the Early Academic Enablers. As attentional focusing increased, approaches to learning and communication skills also increased. No statistical significance was found with the other subdimensions of the Early Academic Enablers

The attentional shifting of the Effortful Control positively predicted the gross motor skills $n$ of the Early Academic Enablers. An increase in attentional shifting resulted in an increase in gross motor skills. A statistical significance was not determined with the other subdimensions of the Early Academic Enablers.

The perceptual sensitivity of the Effortful Control positively predicted the approaches to learning and communication skills of the Early Academic Enablers. As perceptual sensitivity increased, approaches to learning and communication skills also increased. On the other hand, no statistical significance could be found with the other of the Early Academic Enablers

The low intensity pleasure of the Effortful Control positively predicted the social and emotional competence of the Early Academic Enablers whereas no statistical significance was determined with the other subdimensions of the Early Academic Enablers As scores for low intensity pleasure increased, social and emotional competence also increased.

The behaviour regulation positively predicted the social and emotional competence, fine motor skills and communication skills subdimensions of the Early Academic Enablers. As Behavior regulation increased, social and emotional competence, fine motor skills and communication skills also increased.

Abstraction skills positively predicted the approaches to learning of the Early Academic Enablers. An increase in abstraction skills also caused an increase in approaches to learning.

\section{Discussion and Conclusion}

The aim of this study was to examine the direct and indirect relationships among children's self-regulation skills (behaviour regulation and effortful control), their higher-order cognitive skills of abstraction skills and cognitive flexibility, and their early academic skills and early academic e

The results obtained in the study are consistent with findings of previous studies examining the effects of executive functions on academic competence.

The children's attentional focusing and perceptual sensitivity aspects of effortful control and their behaviour regulation positively predicted their critical thinking skills in early academic skills while attentional focusing, perceptual sensitivity and behaviour regulation predicted critical thinking skills in early academic skills, perceptual sensitivity also predicted early literacy skills in early academic skills. The low intensity pleasure aspect of effortful control predicted comprehension skills in early academic skills. As low intensity pleasure increased, 
comprehension skills also increased.

It was determined that behavioural regulation predicted the numeracy, early literacy skills and comprehension skills of early academic competence.

A significant relationship was not found for abstraction skills and cognitive flexibility with early academic skills. When the effect of the children's self-regulation skills on their early academic enablers was examined, it was determined that the inhibitory control of effortful control predicted the social and emotional competence of early academic enablers. The attentional focusing skill of effortful control was a significant predictor of approaches to learning and communication skills in early academic enablers. Furthermore, it was revealed that the attentional shifting skill of effortful control predicted gross motor skills in early academic enablers. Both perceptual sensitivity and attentional focusing predicted approaches to learning. The low intensity pleasure aspect of effortful control predicted social and emotional competence.

Behavioural regulation, however, predicted the social and emotional competence, fine motor skills and communication skills subdimensions of early academic enablers. Abstraction skills predicted approaches to learning in early academic enablers.

In this study, to determine which subdimensions of effortful control were associated with early academic skills and early academic enablers, the subdimensions of effortful control are dealt with one by one. When the related literature is examined, it is seen that in studies in which children's effortful control is determined with scores obtained from teachers, an examination of the relationship of the subdimensions of effortful control with early academic competence and early academic enablers is overlooked. Researchers are generally revealed to have examined total scores calculated for effortful control in its relationship with academic skills (e.g., Blair \& Razza, 2007; Fabes et al., 2003; Jahromi et al., 2017; Zhang \& Rao, 2017). Moreover, in the study, in the relationship of behaviour regulation with early academic competence and early academic enablers, the subdimensions of early academic competence and early academic enablers are examined one by one. Similarly, in the relationships of abstraction skills and cognitive flexibility with early academic competence and early academic enablers, these are examined separately for each subdimension of early academic competence and early academic enablers.

Effortful control and behaviour regulation are important components of self-regulation (Zhou, Chen, \& Main, 2012; McClelland et al., 2007). In the current study, it was revealed that effortful control especially predicted the creative thinking, critical thinking and early literacy skills subdimensions of early academic competence. Moreover, it was determined that behavioural regulation predicted early literacy and that effortful control predicted comprehension skills. These results show similarity with findings in the literature. Effortful control, which has a self-regulatory structure that originates from temperament-based frameworks (Rothbart \& Bates, 2006), is consistently associated with children's higher early academic skills (Eisenberg, Valiente, \& Eggum, 2010; Liew, 2012). Therefore, it is not surprising that the findings of the present study are consistent with those in the literature. They are similar to previous studies conducted with samples of preschool children (Allan \& Lonigan, 2014; Allan \& Lonigan, 2011; Bull et al., 2011; Denham et al., 2012). In their study, Allan and Lonigan (2014) found that effortful control was significantly correlated with academic competencies. Furthermore, in their meta-analysis study, Allan et al. (2014) revealed a moderate statistically significant relationship between self-regulation and academic competencies. Behavioural regulation and executive functions (effortful control, attentional or cognitive flexibility, working memory and inhibitory control), which form the components of children's self-regulation, are stated to be strong indicators of academic achievement (McClelland et al., 2007; McClelland, Acock, \& Morrison, 2006). Effortful control is discussed in a comprehensive temperament context affecting many aspects of young children's typical and atypical development, and is considered as a significant individual difference (Allan \& Lonigan, 2011; Kochanska et al., 2007). The results of this study correspond with Blair and Razza's (2007) study. Similar findings were made in both studies. In preschool children, effortful control is related to academic performance and level of readiness for school and is a predictor of these. In this study, it was determined that low intensity pleasure, which is a subdimension of effortful control, predicted comprehension skills. Testing comprehension skills in young children is not simple. Generally, comprehension skill, which is a core language skill, is included within reading skills and expressed as reading comprehension skill. Early literacy includes both language comprehension skills and writing/decoding skills (Scarborough, 2001; Whitehurst \& Lonigan, 1998). However, since reading skills in young children have not yet developed, reading-based comprehension skills cannot be determined. Studies conducted on young children (e.g., preschool, nursery school) are limited, since it is difficult to assess comprehension skills in individuals who do not possess reading skills (Bourg, Bauer, \& van den Broek, 1997). Nevertheless, comprehension can be evaluated without the reading of texts by showing stories with pictures in different environments. For example, pictures in stories can be presented aurally or using television (Van den Broek, Lorch, \& Thurlow, 1996). Comprehension skills are associated with 
early literacy skills in children at a young age. For example, in the study conducted by Kendeou et al. (2005), core language skills were found to be closely correlated amongst themselves, and especially, a strong relationship was found between children's letter and word recognition skills and their phonological awareness. Vocabulary knowledge was found to be highly correlated with both comprehension skills and core language skills. These findings suggest that comprehension skills acquired at an early age can support reading comprehension skills in primary school in the same way as they support vocabulary and other core language skills (e.g., letter and word recognition, phonological awareness) (Kendeou et al., 2005). As a result of the present study, it was determined that effortful control was correlated with both the early literacy and comprehension skills subdimensions of early academic competence. The finding that early literacy and comprehension skills are related supports this data. Moreover, it is likely that children with high levels of effortful control will show skill in adaptive behavioural regulation, planning, continuity, attention, flexibility and organisation during learning activities. Moreover, effortful control can support regulation of emotional reactions (e.g., disappointment, fear), and in this way, children experiencing these emotions can continue with challenging activities and interact with teachers (Wass, Scerif, \& Johnson, 2012). By enabling emotional regulation, effortful control can support children's comprehension skills by helping them to focus and maintain their attention. More detailed research needs to be conducted into the effects of effortful control and executive functions on comprehension skills in children's early academic competence.

In the preschool period, behaviour regulation plays an important role in predicting the early literacy and early mathematical skills of children's early academic competence (McClelland, Acock, \& Morrison, 2006; McClelland et al., 2007; Ponitz, McClelland, Matthews, \& Morrison, 2009; McClelland, Cameron, Connor, Farris, Jewkes, \& Morrison, 2007; Sektnan, McClelland, Acock, \& Morrison, 2010; Lonigan, Allan, \& Phillips, 2017). The study revealed that as behaviour regulation scores increased, early literacy skills in children's early academic competence also increased. This finding shows similarity with those of other studies. Many studies can be found in the literature with evidence to the effect that behaviour regulation skills predict early academic competence (McClelland et al., 2006; McClelland et al., 2007; McClelland \& Morrison, 2003; Wanless et al., 2013; Ertürk-Kara, 2017; Shaul \& Schwartz, 2014; Lonigan, Allan, \& Phillips, 2017). Furthermore, behaviour regulation is also a predictor of readiness for school. The current study supports the idea of measuring children's school readiness before they start school, since self-regulation plays a critical role in children's readiness for school and their early academic development (Eisenberg et al., 2010; Ursache et al., 2012). Current studies show that executive functions have more effect than IQ on pre-literacy and mathematical thinking in terms of readiness for first grade (Shaul \& Schwartz, 2014). The results of this study are such as to support the findings of conducted studies. For example, Wanless et al. (2013) revealed that there was a direct relationship between behaviour regulation and school readiness. In the study conducted by Blair and Raver (2015), it was revealed that the dimensions of self-regulation, including emotional regulation and executive function, were important skills necessary for school readiness and early academic achievement. In the current study, while early academic competences were being determined, in fact, readiness for school was also determined, since in the study, along with early academic competence, preschool children's behaviour regulation skills and executive functions were measured, and especially working memory, attention and inhibitory control were determined. In the study, behaviour regulation predicted numeracy and comprehension skills in early academic competence. When scores for behaviour regulation skills increased, scores for numeracy and comprehension skills also increased. There are many studies in the literature which state that behaviour regulation is a predictor of mathematics skills (e.g., Bull, Espy, \& Wiebe, 2008; Blair, Knipe, \& Gamson, 2008; Bull \& Lee, 2014; Espy, McDiarmid, Cwik, Stalets, Hamby, \& Senn, 2004; Shaul \& Schwartz, 2014; Clark, Pritchard, \& Woodward, 2010). The relationship between behavioural self-regulation and executive function skills (including attentional or cognitive flexibility, working memory and inhibitory control) is a strong predictor of development in children's success in mathematics in particular (Blair \& Razza, 2007; Ponitz et al., 2009; Bull et al., 2011). Ertürk-Kara (2017) revealed that children's behaviour regulation and interpersonal social skills as a whole predicted their mathematics skills. Especially behaviour regulation skills make a specific contribution to the model created to explain children's skills of number/operation/counting awareness, measurement awareness, data collection/statistical awareness, and geometric/spatial logic awareness. In the study made by Bull, Espy and Wiebe (2008), visual-spatial short-term memory span was determined to be a predictor of mathematical ability in particular. Correlational and regression analyses showed that visual short-term and working memory predicted specifically mathematics success, while executive function skills predicted learning in general rather than learning in a specific domain. The results of the present study are such as to support these findings.

In the literature, the relationship between early literacy and arithmetic competence was stated in the findings of other studies related to development of early academic competence. Early literacy is correlated with arithmetic 
skills (Duncan et al., 2007; Howse et al., 2003; Pagani, Fitzpatrick, Archambault, \& Janosz, 2010). The findings in the related literature support the present study in two ways. Firstly, in the study, it was concluded that behaviour regulation predicted both early literacy and numeracy in early academic competence. Secondly, this finding also reveals the relationship between early literacy skills and mathematical skills. Suchodolets et al. (2009) determined that there was a positive relationship of behaviour regulation with academic performance and behaviours in class. Although children's academic competences were determined in the current study, in fact, their readiness for school was also determined together with them. Based on the studies they carried out with primary school children, DiPerna and Elliott (1999) proposed an "academic competence" model which distinguished the areas of academic skills and other classroom behaviours that contribute to success in class from each other. Considering the parallels between school readiness in DiPerna and Elliott's academic competence model, in the present study, behaviour regulation and effortful control, which are two important skills of self-regulation, were also shown to predict readiness for school. This finding supports the findings in the literature. For example, Wanless et al. (2013) showed that behaviour regulation was directly related to school readiness. In another study, preschool children with strong behavioural regulation achieved greater academic success in the school period after child IQ was checked (Von Suchodoletz et al., 2009). There is continuing strong evidence that behavioural regulation and effortful control are significant predictors of academic outcomes even after basic achievement levels, child IQ and a series of demographic variables have been checked (e.g., McClelland et al., 2006, 2007, 2013; Blair \& Razza, 2007; Moffitt et al., 2011). In examples in the preschool and kindergarten period, effortful control is associated with academic performance and school readiness status and is a predictor of these (Blair \& Razza, 2007). In the current study, we found that effortful control predicted academic competence in preschool. This is an important finding, since Welsh et al. (2010) emphasise the importance of working memory and attentional control, as working memory and attentional control, which are important components of executive functions, predict the development of emergent literacy and arithmetic skills during the preschool year, and recommend that studies are conducted to reveal their effects in the early childhood period prior to starting school.

The findings obtained from this study support our hypothesis that generally, the components of executive functions are clearly correlated with the components of early numeracy and literacy. This study expands on previous studies regarding the relationship between executive functions and academic skills (Welsh et al., 2010; Clark, Pritchard, \& Woodward, 2010; Clements, Sarama, \& Germeroth, 2016; Lan, Legare, Ponitz, \& Morrison, 2011).

On the other hand, what is unique about this study is the conclusion that effortful control and behaviour regulation, which make up the structure of self-regulation, are not only related to early literacy and mathematical ability, but also predict the critical thinking and creative thinking skills of early academic competence. Especially, attentional focusing and perceptual sensitivity in effortful control are positive predictors of creative thinking skills. Furthermore, along with attentional focusing and perceptual sensitivity, behaviour regulation predicts critical thinking. The creative thinking factor includes components related to generating new thoughts and ideas, while the critical thinking factor includes the reasoning and analytical skills components (Reid, DiPerna, Missall, \& Volpe, 2014). In the present study, it was determined that behaviour regulation predicted critical thinking and that effortful control predicted creative thinking. When the literature is examined, although no studies, to our knowledge, can be found regarding the relationship of executive functions with preschool children's creative thinking and critical thinking, creativity has been associated with higher order cognitive functions, especially executive functions, and it is assumed that creative thinking tests reflect these functions (e.g., Naglieri \& Kaufman, 2001). These higher-order cognitive skills are known collectively as "executive functions", since in order to generate higher-level creative and abstract thinking, they utilise more basic or primary cognitive skills such as attention, language and perception (Delis, Lansing, Houston, Wetter et al., 2007). Neurobiological models of executive function have stressed a close connection of the key role played by the frontal and especially prefrontal cortex (e.g., Banich, 2009) and development of executive functions with refinement of prefrontal cortical networks (Diamond, 2002). Moreover, creativity requires this type of executive functional ability generally attributed to the prefrontal cortex (Bekhtereva, Dan'ko, Starchenko, Pakhomov, \& Medvedev, 2001). When considered from this viewpoint, the finding of the study supports the data. On the other hand, a contrasting finding was obtained in the study by Scibinetti, Tocci, and Pesce (2011). In the study, the effect of inhibitory control on motor creativity and creative thinking in children aged 7-8 was examined, and as a result, it was found that originality in thinking was predicted by low inhibitory control. There is a need for research to support the findings of the study in this regard.

When the effect of children's self-regulation skills on their academic enablers was examined, effortful control significantly predicted social and emotional competence, approaches to learning and communication skills. Moreover, effortful control predicted gross motor skills. The finding that effortful control predicted approaches to learning and communication skills shows consistency with findings in the literature. For example, the finding by 
Eisenberg, Zhou et al. (2005) and Zhou et al., (2007), obtained with a parent assessment scale, that preschool children's effortful control was related to social competence or low problematic behaviours, is also encountered in other studies. In the study by Liew, McTigue, Barrois, and Hughes (2008), it was determined that effortful control in first grade contributed to positive academic self-competence beliefs in second grade. Since effortful control is an aspect of temperament that contributes to attention, effort and retention, it is not surprising that early effortful control contributes to later academic self-competence beliefs (Liew, McTigue, Barrois, \& Hughes, 2008; Fantuzzo et al., 2007). It is believed that effortful control in children affects their social functions by contributing to the way emotions are altered and knowledge is processed. In being able to keep their behaviours in check and abiding by social standards, children refrain from excessive or aggressive behaviours in social interactions and are more likely to behave in socially acceptable ways. For example, it was found that boys aged 4-6 who obtained high scores in the components of effortful control used non-aggressive verbal strategies when they were angry rather than resorting to physical strategies (Eisenberg, Fabes, Nyman, Bernzweig, \& Pinuelas, 1994). Furthermore, in the study by Valiente et al. (2011), it was revealed that children with high levels of effortful control displayed good performance at school. Researchers explain that part of the reason for this is that children are relatively competent in terms of social behaviours. It is thought that more than one process is involved in the role of effortful control in children's academic development. For example, it can be expected that when children with higher levels of effortful control are engaged in school work, they will maintain their attention better, they will be better at regulating their emotions and emotional impulses in their peer and classroom interactions, and they will be more motivated, attentive and persistent in their learning (Chang \& Burns, 2005; Eisenberg, Smith, Sadovsky, \& Spinrad, 2004; Eisenberg, Spinrad et al., 2004; Liew, 2012; Valiente et al., 2011). Therefore, in the present study, it was concluded that effortful control not only predicted children's early academic skills, it also predicted children's social and emotional competence. Consequently, the hypothesis that social competence in children has a positive effect on academic performance and that they are interrelated is supported (Valiente et al., 2008; Welsh et al., 2001; Wentzel et al., 2009; Blair, 2002; Bronson, Tivnan, \& Seppanen, 1995; Wentzel et al., 2009). Children whose effortful control is low can display destructive and aggressive behaviours, in which case, they will receive less support than their peers and this will also have a negative effect on their academic performance. This is significant when considering that a number of education models especially require students to interact socially in small group environments; it is unlikely that students who have problems with respect to peers will benefit from peer cooperation or cooperative learning groups (Valiente et al., 2011). In our study, it was seen that effortful control was a significant predictor of social and emotional competence, approaches to learning and communication skills. When the findings of conducted studies and of our study are examined, developed effortful control in children affects their social competence, this situation has a positive effect on their relationships with their peers or teachers, and in such an atmosphere, children can also be successful academically. Social development and academic success are correlated. In a classroom environment, a child with high social acceptance may also be more willing to learn, since social and emotional competence increases children's success in an academic sense (Duncan et al., 2007). It is thought that the characteristics of effortful control are important for motivation and participation in school environments (Rothbart \& Jones, 1998). In the study, we have provided evidence for this idea. Effortful control affects social and emotional competence as well as approaches to learning. Academic performance is also increased. Zhou et al.'s (2010) study supports these findings. In their study, they suggested that children with high effortful control developed higher social competence and that this in turn helped them to obtain more social, emotional and instructional resources. Therefore, it is probable that children who possess the skill of effortful control will become people who are good at developing and maintaining positive school relationships, and that effortful control can provide children with a support network for learning and future success (Liew, 2011). In our study, we examined whether or not effortful control predicted early academic skills, and as a result, we ascertained that it affected skills ranging from early literacy and mathematical skills to social and emotional competence, approaches to learning and communication skills, and this finding supports the hypothesis that it affects all the early academic skills. The conducted studies demonstrate that especially, effortful control, which has a self-regulatory structure originating from temperament-based frameworks (Rothbart \& Bates, 2006), is consistently associated with children's early academic skills and is regarded as one of the critical components that determine early academic success (Eisenberg et al., 2010, Liew, 2012).

In our study, it was determined that effortful control and behaviour regulation, which are among the attitudes enabling early academic success, predicted the psychomotor skills of fine motor and gross motor skills. Although to our knowledge, there are only a minimal number of studies in the literature regarding the effect of effortful control on psychomotor skills, we did come across related studies. For example, Wassenberg et al. (2005) revealed that in children aged 5-6, motor skills were related to performance in cognitive functions including the areas of attentional and executive functions. Bushnell and Boudreau (1993) supported the idea that motor development can 
determine the order of formation of perceptive and cognitive competences. For instance, low motor skills may be a warning sign of possible problems related to language development and attention skills in the early childhood period. It was revealed that motor development observed over a four-year period (from four months to four years) was able to predict children's motor and cognitive performances when they reached school age (Piek et al., 2008). For example, in the study by Sarnadinha, Pereira, Cruz-Ferreira, Fernandes, and Veiga (2018), which examined the feasibility and effect of psychomotor therapy on preschool children's executive and socio-emotional functions in creative dance, it was seen that the intervention they implemented resulted in an increase in children's working memory and a reduction in their reactive aggression levels. Psychomotor development is key to children's general development, and can be defined as the development and integration of cognitive, emotional, symbolic and emotional-motor interactions that affect children's capacity to express themselves in a psychosocial context (Cueto et al., 2017). This process involves the development of basic (a) physical skills such as movement and coordination, and (b) psychological skills such as emotional self-control (Romero-Martínez, Ordóñez-Camacho, \& Gil-Madrona, 2018). Psychomotor training is the beginning of the early childhood education process. Learning difficulties identified in the child may result in a delay in psychomotor development. A child showing weak psychomotor development may have problems in gaining psychomotor skills and at the same time, show problems in writing, reading, word syllabification, arranging syllables, abstract thinking and logical and grammatical analysis (Ross1, 2012). Studies reveal that there are schoolchildren who have adaptation problems related to clear difficulties in their motor performances (social behaviour skills, aggression, isolation, lack of empathy, and emotional disorders) (cited by Zaragas \& Pliogou, 2020). Moreover, in a study aimed at examining whether information from kinetic performance measures from birth up to four years could predict kinetic and cognitive performance, a relationship was found between motor skills and symptoms of anxiety and depression. Further analyses revealed a significant predictive relationship for gross motor trajectory information and the subtests of working memory and processing speed (Piek et al., 2008a, 2008b). The results also revealed that at this age, good motor performance and stabilisation showed a positive correlation with cognitive competence and especially processing speed of information processing. Moreover, Hernandez and Cacola's (2015) study examined the relationship between four-year-old preschool children's motor performances and cognitive competencies. In the study, the results revealed a positive correlation between kinetic performance and verbal expression. In particular, manual coordination of upper extremities was a significant predictor and determined IQ and general scores for kinetic performance. In other words, effortful control and behaviour regulation, which affect early academic skills, have a significant effect on readiness for school in reality. When early academic skills are examined, early literacy generally appears before us. In fact, fine and gross motor skills are important skills whose relationship with children's school readiness should be examined. While readiness for school, or lack of it, is being evaluated, the child's motor skill development should be given strong consideration, and there should perhaps be a standard syllabus for interventions beginning at preschool level (Hernandez \& Cacola, 2015). By means of a weekly programme of motor skill activities at preschool level, improvements in cognitive competencies can be enabled (Draper et al., 2012). The current study shows that effortful control and behaviour regulation also predict children's fine and gross motor skills. Therefore, to support preschool children's early academic skills and readiness for school, effortful control and behaviour regulation skills need to be supported in the early period.

It was determined that behavioural regulation predicted social and emotional competence; fine motor skills and communication skills among early academic behaviours. Starting school requires a number of behavioural regulation skills. Attention orientation, and acquisition and integration of new knowledge, and at the same time, elimination of distractors and control of impulses in a classroom environment may be possible with successful behavioural regulation (Lewit \& Schuurmann-Baker, 1995). Therefore, preschool education emerges as an important channel through which these skills can be acquired (Bowman, Donovan \& Burns, 2001). For this reason, a significant number of studies conducted on executive function skills focus on behavioural regulation skills in the preschool education period (e.g., McClelland et al., 2007; Ponitz et al., 2009). In the present study, it was determined that behavioural regulation skills predicted social and emotional competences in preschool children. The findings of the study are parallel to those in the literature. Study findings reveal that the observed behavioural regulation is correlated with children's socio-emotional and behavioural adaptation. For instance, in the study by Eisenberg et al. (1997), a relationship was found between children's observed behavioural regulation and socially appropriate or adaptive behaviours. Similarly, Eisenberg, Cumberland et al. (2001) showed that low levels of behaviour regulation in children were related to internalising and externalising problem behaviours. In a different study carried out on self-regulation using preschool children's physiological and behavioural regulation, it was revealed that behavioural regulation could be a physiological (temperament-based) mediating mechanism. Behavioural regulation was found to contribute to preschool children's adaptation skills or social competence scores (Liew, Johnson, Smith \& Thoemmes, 2011). In the study, it was determined that behaviour regulation was a 
predictor of fine motor skill, which is an important early academic and school readiness skill. During the preschool period, it is expected that children can master or display behavioural regulation requiring fine motor skills that will be important when they officially start school or receive preschool education, such as drawing with coloured pencils or writing with a pencil. Therefore, behavioural regulation may be a relevant aspect developmentally for focusing on preschool children's fine motor skills and socio-emotional and behavioural adaptation, and for evaluating these (Liew, Johnson, Smith \& Thoemmes, 2011). It can be said that the current finding is consistent with the findings of studies in the literature related to motor functions and academic success. Michel, Roethlisberger, Neuenschwander and Roebers (2011) revealed that children with motor coordination disorders displayed lower pre-academic skills, so that they faced a significant disadvantage when they began formal education. In our study, a statistically significant relationship with early academic competence was not found for abstraction skills or cognitive flexibility, but it was determined that abstraction skills predicted approaches to learning in early academic enablers. Executive functions are cognitive skills such as working memory, inhibitory control and cognitive flexibility involved in performing target-oriented activities (Blair \& Peters, 2003). The two main executive functions involved in these processes are inhibitory control and cognitive flexibility. Although, interestingly, a relationship was not found in our study, when the literature is examined, studies are found which reveal that cognitive flexibility is associated with some of children's early academic skills. For example, Ahçi (2016) revealed that cognitive flexibility developed with age and that it was significantly correlated with receptive language. Similarly, in Deák and Wiseheart's (2015) study, it was found that cognitive flexibility was predicted by variables such as vocabulary size, verbal inhibition, response speed and abstract reasoning. Various studies have associated cognitive flexibility with academic readiness for school acquired success in young children. In a mainly middle-class sample, a positive correlation of cognitive flexibility measured in children aged 4-5 with their literacy and mathematics scores in the first three years of primary school was revealed (Bull, Espy, \& Wiebe, 2008). In the study conducted on preschool children by Bierman, Nix, Greenberg, Blair, and Domitrovich (2008), cognitive flexibility was a positive predictor of learning outcomes in language and literacy. In the present study, it was seen that abstraction skills predicted approaches to learning. Very little is known about the relationships of cognitive flexibility and the other components of children's learning approaches such as attitudes towards learning. Studies conducted on this subject focus on social competence and behaviour problems rather than on learning approaches (e.g. Nigg, Quamma, Greenberg \& Kusché, 1999; Riggs, Blair, \& Greenberg, 2003). Attitudes towards learning include a child's tolerance to disappointment, cooperation and acceptance of help when required (McWayne et al., 2004). In the study by Vitiello, Greenfield, Munis, and George (2011), it was revealed that cognitive flexibility was significantly correlated with children's approaches to learning. Moreover, the researchers suggested that development of children's cognitive flexibility could develop their approaches to learning as well as their academic readiness for school. Children with stronger cognitive flexibility can better select and activate positive approaches to learning in response to learning situations than children with weaker cognitive flexibility (Vitiello, Greenfield, Munis, \& George, 2011). According to Chang and Burns (2005), cognitive flexibility is related to motivation in preschool children. Even though data were obtained in this study to the effect that abstraction skills predicted approaches to learning, there is a need for further research on this subject.

\section{Conclusions and Recommendation}

In the study, to determine which subdimensions of effortful control were associated with early academic success and early academic enablers, the subdimensions were dealt with separately. Moreover, in the study, the relationships of behaviour regulation with early academic competence and early academic enablers were examined separately for the subdimensions of early academic competence and early academic enablers. Similarly, the relationship of cognitive flexibility and abstraction skills with early academic competence and early academic enablers was examined separately for all subdimensions of early academic competence and early academic enablers. It was found that effortful control especially predicted creative thinking, critical thinking and early literacy skills in early academic competence. Moreover, it was determined that behavioural regulation predicted early literacy and that effortful control predicted comprehension skills. As behaviour regulation scores increased, early literacy skills in children's early academic competence also increased. Behaviour regulation and effortful control, which are two important skills of self-regulation, were also shown to predict readiness for school. In the study, it was concluded that behaviour regulation predicted both early literacy and numeracy skills in early academic competence. It was concluded that effortful control and behaviour regulation, which make up the structure of self-regulation, were not only related to early literacy and mathematical ability, but also predicted the critical thinking and creative thinking skills of early academic competence. Effortful control significantly predicted social and emotional competence, approaches to learning and communication skills. Moreover, effortful control predicted gross motor skills. It was revealed that effortful control and behaviour regulation predicted the psychomotor skills of fine motor and gross motor skills, which are early academic enablers. It was determined that 
behavioural regulation predicted social and emotional competence; fine motor skills and communication skills among early academic enablers. A statistically significant relationship with early academic competence was not found for cognitive flexibility or abstraction skills, but it was determined that abstraction skills predicted approaches to learning in early academic enablers.

Early academic skills fostered in children in this period increase children's levels of readiness for school and have a significant effect on their achievement in more advanced academic skills in their later education experience. Studies reveal that children who enter school with a lower level of achievement show a tendency to remain at these levels during their school years. Denton and West (2002), for example, found that children who entered kindergarten with low literacy and arithmetic skills continued to possess low levels of these skills in first grade.

It is also possible for relationships between self-regulation and academic success to be reciprocal in young children. Therefore, in children in the preschool period, self-regulation, behaviour regulation skills and executive functions (short-term memory, inhibitory control) need to be supported, and if there is a weakness, they should definitely be consolidated.

Demographic characteristics were not examined in the study. In future studies, the variables should be examined especially by checking age, gender, socio-economic status and even family status, and the separate effects of these can be examined. By conducting longitudinal research, whether both higher-level cognitive characteristics and early academic skills with self-regulation predict school success can be examined

\section{References}

Adagideli, F, Ural, O., \& Polat, Ö. (2019). Çaba Gerektiren Kontrol Ölçeği’nin Türkçe’ye Uyarlanması. Eğitim Kuram ve Uygulama Araştırmalarl Dergisi, 5(1), 39-52. Retrieved from https://dergipark.org.tr/en/pub/ekuad/issue/44939/559398

Ahçi, Z. G. (2016). 3-5 yas çocuklarinin yürütücü islev performanslari ve dil becerileri ile iliskisi 1. Cumhuriyet International Journal of Education, 5(2), 84-99. Retrieved from https://search.proquest.com/docview/1806623106?accountid=17219

Akın-Sarı, B. (2009). Çocuk davranış listesi kısa formunun Türkçe geçerlilik-güvenilirlik çalışması ve 3-6 yaş çocuklarında mizacın etyolojisinin araştırılması (Yayınlanmamış doktora tezi). Gazi Üniversitesi, Tıp Fakültesi, Ankara.

Allan, N. P., \& Lonigan, C. J. (2011). Examining the dimensionality of effortful control in preschool children and its relation to academic and socioemotional indicators. Developmental Psychology, 47(4), 905. https://doi.org/10.1037/a0023748

Allan, N. P., \& Lonigan, C. J. (2014). Exploring dimensionality of effortful control using hot and cool tasks in a sample of preschool children. Journal of Experimental Child Psychology, 122, 33-47. https://doi.org/10.1016/j.jecp.2013.11.013

Allan, N. P., Hume, L. E., Allan, D. M., Farrington, A. L., \& Lonigan, C. J. (2014). Relations between inhibitory control and the development of academic skills in preschool and kindergarten: A meta-analysis. Developmental Psychology, 50(10), 2368-2379. https://doi.org/10.1037/a0037493

Anderson, P. (2002). Assessment and development of executive function (EF) during childhood. Child Neuropsychology, 8(2), 71-82. https://doi.org/10.1076/chin.8.2.71.8724

Banich, M. T. (2009). Executive function-The search for an integrated account. Current Directions in Psychological Science, 18, 89-94. https://doi.org/10.1111/j.1467-8721.2009.01615.x

Bekhtereva, N. P., Dan'ko, S. G., Starchenko, M. G., Pakhomov, S. V., \& Medvedev, S. V. (2001). Study of the brain organization of creativity: III. Positron-emission tomography data. Human Physiology, 27, 390-397. https://doi.org/10.1023/A:1010946332369

Bierman, K. L., Nix, R. L., Greenberg, M. T., Blair, C., \& Domitrovich, C. E. (2008). Executive functions and school readiness intervention: Impact, moderation, and mediation in the Head Start REDI program. Development and Psychopathology, 20, 821-843. https://doi.org/10.1017/S0954579408000394

Blair, C. (2002). School readiness: Integrating cognition and emotion in a neurobiological conceptualization of children's functioning at school entry. American Psychologist, 57, 111-127. https://doi.org/10.1037/0003-066X.57.2.111

Blair, C., \& Peters, R. (2003). Physiological and neurocognitive correlates of adaptive behavior in preschool among children in Head Start. Developmental Neuropsychology, 24, 479-497. 
https://doi.org/10.1207/S15326942DN2401_04

Blair, C., \& Razza, R. P. (2007). Relating effortful control, executive function, and false belief understanding to emerging math and literacy ability in kindergarten. Child Development, 78(2), 647-663. https://doi.org/10.1111/j.1467-8624.2007.01019.x

Blair, C., Knipe, H., \& Gamson, D. (2008). Is there a role for executive functions in the development of mathematics ability? Mind, Brain, and Education, 2(2), 80-89. https://doi.org/10.1111/j.1751-228X.2008.00036.x

Bourg, T., Bauer, P., \& van den Broek, P. (1997). Building the bridges: The development of event comprehension and representation. Developmental spans in event comprehension and representation. Bridging Fictional and Actual Events, 385-407.

Bowman, B. T., Donovan, M. S., \& Burns, M. S. (2001). Eager To Learn: Educating Our Preschoolers [Full Report and Executive Summary]. National Academy Press, 2101 Constitution Avenue, NW, Lockbox 285, Washington, DC 20055.

Bridgett, D. J., Oddi, K. B., Laake, L. M., Murdock, K. W., \& Bachmann, M. N. (2013). Integrating and differentiating aspects of self-regulation: Effortful control, executive functioning, and links to negative affectivity. Emotion, 13(1), 47-63. https://doi.org/10.1037/a0029536

Bronson, M. B., Tivnan, T., \& Seppanen, P. S. (1995). Relations between teacher and classroom activity variables and the classroom behaviors of prekindergarten children in Chapter 1 funded programs. Journal of Applied Developmental Psychology, 16(2), 253-282. https://doi.org/10.1016/0193-3973(95)90035-7

Bryce, D., Whitebread, D., \& Szücs, D. (2015). The relationships among executive functions, metacognitive skills and educational achievement in 5 and 7 year-old children. Metacognition and Learning, 10(2), 181-198. https://doi.org/10.1007/s11409-014-9120-4

Bull, R., \& Lee, K. (2014). Executive functioning and mathematics achievement. Child Development Perspectives, 8(1), 36-41. https://doi.org/10.1111/cdep.12059

Bull, R., Espy, K. A., \& Wiebe, S. A. (2008). Short-term memory, working memory, and executive functioning in preschoolers: Longitudinal predictors of mathematical achievement at age 7 years. Developmental Neuropsychology, 33(3), 205-228. https://doi.org/10.1080/87565640801982312

Bull, R., Espy, K. A., Wiebe, S. A., Sheffield, T. D., \& Nelson, J. M. (2011). Using confirmatory factor analysis to understand executive control in preschool children: Sources of variation in emergent mathematic achievement. Developmental Science, 14(4), 679-692. https://doi.org/10.1111/j.1467-7687.2010.01012.x

Bushnell, E. W., \& Boudreau, J. P. (1993). Motor development and the mind: The potential role of motor abilities as a determinant of aspects of perceptual development. Child Development, 64(4), 1005-1021. https://doi.org/10.2307/1131323

Campbell, C., Landry, O., Russo, N., Flores, H., Jacques, S., \& Burack, J. A. (2013). Cognitive flexibility among individuals with Down syndrome: assessing the influence of verbal and nonverbal abilities. American Journal on Intellectual and Developmental Disabilities, 118(3), 193-200. https://doi.org/10.1352/1944-7558-118.3.193

Chang, F., \& Burns, B. M. (2005). Attention in preschoolers: Associations with effortful control and motivation. Child Development, 76(1), 247-263. https://doi.org/10.1111/j.1467-8624.2005.00842.x

Clark, C. A., Pritchard, V. E., \& Woodward, L. J. (2010). Preschool executive functioning abilities predict early mathematics achievement. Developmental Psychology, 46(5), 1176. https://doi.org/10.1037/a0019672

Clements, D. H., Sarama, J., \& Germeroth, C. (2016). Learning executive function and early mathematics: Directions of causal relations. Early Childhood Research Quarterly, 36, 79-90. https://doi.org/10.1016/j.ecresq.2015.12.009

Cueto, S., Prieto, J. A., Nistal, P., Abelairas-Gómez, C., Barcala-Furelos, R., \& López, S. (2017). Teachers' perceptions of preschool children's psychomotor development in Spain. Perceptual and Motor Skills, 124(4), 725-739. https://doi.org/10.1177/0031512517705534

Davidson, M. C., Amso, D., Anderson, L. C., \& Diamond, A. (2006). Development of cognitive control and executive functions from 4 to 13 years: Evidence from manipulations of memory, inhibition, and task switching. Neuropsychologia, 44(11), 2037-2078. https://doi.org/10.1016/j.neuropsychologia.2006.02.006 
Deák, G. O., \& Wiseheart, M. (2015). Cognitive flexibility in young children: General or task-specific capacity? Journal of Experimental Child Psychology, 138, 31-53. https://doi.org/10.1016/j.jecp.2015.04.003

Delis, D. C., Lansing, A., Houston, W. S., Wetter, S., Han, S. D., Jacobson, M., ... \& Kramer, J. (2007). Creativity lost: The importance of testing higher-level executive functions in school-age children and $\begin{array}{llll}\text { adolescents. Journal of Psychoeducational Assessment, 25(1), 29-40. } & \text {. }\end{array}$ https://doi.org/10.1177/0734282906292403

Denham, S. A., Warren-Khot, H. K., Bassett, H. H., Wyatt, T., \& Perna, A. (2012). Factor structure of self-regulation in preschoolers: Testing models of a field-based assessment for predicting early school readiness. Journal of Experimental Child Psychology, 111(3), 386-404. https://doi.org/10.1016/j.jecp.2011.10.002

Denissen, J. J., Zarrett, N. R., \& Eccles, J. S. (2007). I like to do it, I'm able, and I know I am: Longitudinal couplings between domain-specific achievement, self - concept, and interest. Child Development, 78(2), 430-447. https://doi.org/10.1111/j.1467-8624.2007.01007.x

Denton, K., \& West, J. (2002). Children's reading and mathematics achievement in kindergarten and first grade. National Center for Education Statistics, Office of Educational Research and Improvement, US Department of Education. https://doi.org/10.1037/e492182006-005

Diamond, A. (2002). Normal development of prefrontal cortex from birth to young adulthood: Cognitive functions, anatomy, and biochemistry. In D. T. Stuss, \& R. T. Knight (Eds.), Principles of frontal lobe function (pp. 466-503). New York: Oxford University Press. https://doi.org/10.1093/acprof:oso/9780195134971.003.0029

Dick, A. S. (2014). The development of cognitive flexibility beyond the preschool period: an investigation using a modified Flexible Item Selection Task. Journal of Experimental Child Psychology, 125, 13-34. https://doi.org/10.1016/j.jecp.2014.01.021

DiPerna, J. C. (2004). Structural and concurrent validity evidence for the academic competence evaluation scales-college edition. Journal of College Counseling, 7(1), 64-72. https://doi.org/10.1002/j.2161-1882.2004.tb00260.x

DiPerna, J. C., \& Elliott, S. N. (1999). Development and validation of the academic competence evaluation $\begin{array}{lllll}\text { scales. Journal of Psychoeducational Assessment, } & \text { 17(3), }\end{array}$ https://doi.org/10.1177/073428299901700302

DiPerna, J. C., \& Elliott, S. N. (2002). Promoting academic enablers to improve student achievement: An introduction to the mini-series. School Psychology Review, 31(3), 293-297

Draper, C. E., Achmat, M., Forbes, J., \& Lambert, E. V. (2012). Impact of a community-based programme for motor development on gross motor skills and cognitive function in preschool children from disadvantaged $\begin{array}{lllll}\text { settings. Early Child Development and Care, 182(1), } & \text { 137-152. }\end{array}$ https://doi.org/10.1080/03004430.2010.547250

Duncan, G. J., Dowsett, C. J., Claessens, A., Magnuson, K., Huston, A. C., Klebanov, P., ... \& Sexton, H. (2007). School readiness and later achievement. Developmental Psychology, 43(6), 1428. https://doi.org/10.1037/0012-1649.43.6.1428

Eisenberg, N., Fabes, R. A., Nyman, M., Bernzweig, J., \& Pinuelas, A. (1994). The relations of emotionality and regulation to children's anger-related reactions. Child Development, 65, 109-128. https://doi.org/10.2307/1131369

Eisenberg, N., Fabes, R. A., Shepard, S. A., Murphy, B. C., Guthrie, I. K., Jones, S., .. \& Maszk, P. (1997). Contemporaneous and longitudinal prediction of children's social functioning from regulation and emotionality. Child Development, 68(4), 642-664. https://doi.org/10.2307/1132116

Eisenberg, N., Gershoff, E. T., Fabes, R. A., Shepard, S. A., Cumberland, A. J., Losoya, S. H., ... \& Murphy, B. C. (2001). Mother's emotional expressivity and children's behavior problems and social competence: Mediation through children's regulation. Developmental Psychology, 37(4), 475. https://doi.org/10.1037/0012-1649.37.4.475

Eisenberg, N., Smith, C. L., Sadovsky, A., \& Spinrad, T. L. (2004). Effortful control. Handbook of self-regulation: Research, Theory and Applications (pp. 259-282).

Eisenberg, N., Spinrad, T. L., Fabes, R. A., Reiser, M., Cumberland, A., Shepard, S. A., ... \& Thompson, M. 
(2004). The relations of effortful control and impulsivity to children's resiliency and adjustment. Child Development, 75(1), 25-46. https://doi.org/10.1111/j.1467-8624.2004.00652.x

Eisenberg, N., Valiente, C., \& Eggum, N. D. (2010). Self-regulation and school readiness. Early Education and Development, 21(5), 681-698. https://doi.org/10.1080/10409289.2010.497451

Eisenberg, N., Zhou, Q., Spinrad, T. L., Valiente, C., Fabes, R. A., \& Liew, J. (2005). Relations among positive parenting, children's effortful control, and externalizing problems: A three-wave longitudinal study. Child Development, 76(5), 1055-1071. https://doi.org/10.1111/j.1467-8624.2005.00897.x

Elliott, S. N., DiPerna, J. C., Mroch, A. A., \& Lang, S. C. (2004). Prevalence and patterns of academic enabling behaviors: An analysis of teachers' and students' ratings for a national sample of students. School Psychology Review, 33(2), 302-309.

Ertürk-Kara, H. G. (2017). Çocukların davranışsal becerilerinin erken akademik becerilerini yordamadaki rolü. Uluslararası Sosyal Araştırmalar Dergisi, 10(49), 432-441. https://doi.org/10.17719/jisr.2017.1595

Ertürk-Kara, H. G., Gönen, M. S., \& Pianta, R. (2017). The examination of the relationship between the quality of teacher-child interaction and children's self-regulation skills. Hacettepe Üniversitesi Eğitim Fakültesi Dergisi (H. U. Journal of Education) 32(4), 880-895.

Espy, K. A., McDiarmid, M. M., Cwik, M. F., Stalets, M. M., Hamby, A., \& Senn, T. E. (2004). The contribution of executive functions to emergent mathematic skills in preschool children. Developmental Neuropsychology, 26(1), 465-486. https://doi.org/10.1207/s15326942dn2601_6

Fabes, R. A., Martin, C. L., Hanish, L. D., Anders, M. C., \& Madden-Derdich, D. A. (2003). Early school competence: The roles of sex-segregated play and effortful control. Developmental Psychology, 39(5), 848. https://doi.org/10.1037/0012-1649.39.5.848

Fantuzzo, J., Bulotsky-Shearer, R., McDermott, P. A., McWayne, C., Frye, D., \& Perlman, S. (2007). Investigation of dimensions of social-emotional classroom behavior and school readiness for low-income urban preschool children. School Psychology Review, 36(1), 44-62.

Gentner, D., \& Lowenstein, J. (2002). Language, literacy, and cognitive development: The development and consequences of symbolic communication, chapter Relational language and relational thought.

Geurts, H. M., Corbett, B., \& Solomon, M. (2009). The paradox of cognitive flexibility in autism. Trends in cognitive sciences, 13(2), 74-82. https://doi.org/10.1016/j.tics.2008.11.006

Hampton, J. A. (2003). Abstraction and context in concept representation. Philosophical Transactions of the Royal Society of London. Series B: Biological Sciences, 358(1435), 1251-1259. https://doi.org/10.1098/rstb.2003.1314

Hernandez, A. M., \& Caçola, P. (2015). Motor proficiency predicts cognitive ability in four-year-olds. European Early Childhood Education Research Journal, 23(4), 573-584. https://doi.org/10.1080/1350293X.2014.991094

Howse, R. B., Calkins, S. D., Anastopoulos, A. D., Keane, S. P., \& Shelton, T. L. (2003). Regulatory contributors to children'skindergarten achievement. Early Education and Development, 14, 101-119. https://doi.org/10.1207/s15566935eed1401_7

Hughes, C., \& Ensor, R. (2007). Executive function and theory of mind: Predictive relations from ages 2 to 4 . Developmental Psychology, 43(6), 1447. https://doi.org/10.1037/0012-1649.43.6.1447

Jacques, S., \& Zelazo, P. D. (2001). The Flexible Item Selection Task (FIST): A measure of executive function in $\begin{array}{llll}\text { preschoolers. } & \text { Developmental }\end{array}$ https://doi.org/10.1207/S15326942DN2003_2

Jahromi, L. B., Zeiders, K. H., Updegraff, K. A., Umaña-Taylor, A. J., \& Bayless, S. D. (2018). Coparenting conflict and academic readiness in children of teen mothers: Effortful control as a mediator. Family process, 57(2), 462-476. https://doi.org/10.1111/famp. 12290

Kendeou, P., Lynch, J. S., Van Den Broek, P., Espin, C. A., White, M. J., \& Kremer, K. E. (2005). Developing successful readers: Building early comprehension skills through television viewing and listening. Early Childhood Education Journal, 33(2), 91-98. https://doi.org/10.1007/s10643-005-0030-6

Kochanska, G., Murray, K. T., \& Harlan, E. T. (2000). Effortful control in early childhood: continuity and change, antecedents, and implications for social development. Developmental Psychology, 36(2), 220-232. 
https://doi.org/10.1037/0012-1649.36.2.220

Kochanska, G., Murray, K., Jacques, T. Y., Koenig, A. L., \& Vandegeest, K. A. (1996). Inhibitory control in young children and its role in emerging internalization. Child Development, 67(2), 490-507. https://doi.org/10.2307/1131828

Lan, X., Legare, C. H., Ponitz, C. C., Li, S., \& Morrison, F. J. (2011). Investigating the links between the subcomponents of executive function and academic achievement: A cross-cultural analysis of Chinese and American preschoolers. Journal of Experimental Child Psychology, 108(3). https://doi.org/10.1016/j.jecp.2010.11.001

Lengua, L. J. (2006). Growth in temperament and parenting as predictors of adjustment during children's transition to adolescence. Developmental Psychology, 42(5), 819-832. https://doi.org/10.1037/0012-1649.42.5.819

Lewit, E. M. \& Schuurmann-Baker, L. (1995). Child indicators: School readiness. The Future of Children, 5, 128-139. https://doi.org/10.2307/1602361

Liew, J. (2012). Effortful control, executive functions, and education: Bringing self-regulatory and social-emotional competencies to the table. Child Development Perspectives, 6(2), 105-111. https://doi.org/10.1111/j.1750-8606.2011.00196.x

Liew, J., Johnson, A. Y., Smith, T. R., \& Thoemmes, F. (2011). Parental expressivity, child physiological and behavioral regulation, and child adjustment: Testing a three-path mediation model. Early Education \& Development, 22(4), 549-573. https://doi.org/10.1080/10409289.2010.481551

Liew, J., McTigue, E. M., Barrois, L., \& Hughes, J. N. (2008). Adaptive and effortful control and academic self-efficacy beliefs on achievement: A longitudinal study of 1st through 3rd graders. Early Childhood Research Quarterly, 23(4), 515-526. https://doi.org/10.1016/j.ecresq.2008.07.003

Lonigan, C. J., Allan, D. M., \& Phillips, B. M. (2017). Examining the predictive relations between two aspects of self-regulation and growth in preschool children's early literacy skills. Developmental Psychology, 53(1), 63. https://doi.org/10.1037/dev0000247

Matthews, J. S., Marulis, L. M., \& Williford, A. P. (2014). Gender processes in school functioning and the mediating role of cognitive self-regulation. Journal of Applied Developmental Psychology, 35(3), 128-137. https://doi.org/10.1016/j.appdev.2014.02.003

McClelland, M. M. \& Cameron, C. E. (2012). Self-regulation in early childhood: Improving conceptual clarity and developing ecologically valid measures. Child Development Perspectives, 6(2), 136-142. https://doi.org/10.1111/j.1750-8606.2011.00191.x

McClelland, M. M., \& Morrison, F. J. (2003). The emergence of learning-related social skills in preschool $\begin{array}{lllll}\text { children. Early } \quad \text { Childhood Research } & \text { 206-224. }\end{array}$ https://doi.org/10.1016/S0885-2006(03)00026-7

McClelland, M. M., Acock, A. C., \& Morrison, F. J. (2006). The impact of kindergarten learning-related skills on academic trajectories at the end of elementary school. Early Childhood Research Quarterly, 21(4), 471-490. https://doi.org/10.1016/j.ecresq.2006.09.003

McClelland, M. M., Acock, A. C., Piccinin, A., Rhea, S. A., \& Stallings, M. C. (2013). Relations between preschool attention span-persistence and age 25 educational outcomes. Early Childhood Research Quarterly, 28(2), 314-324. https://doi.org/10.1016/j.ecresq.2012.07.008

McClelland, M. M., Cameron, C. E., Connor, C. M., Farris, C. L., Jewkes, A. M., \& Morrison, F. J. (2007). Links between behavioral regulation and preschoolers' literacy, vocabulary, and math skills. Developmental Psychology, 43(4), 947. https://doi.org/10.1037/0012-1649.43.4.947

McClelland, M. M., Cameron, C. E., Wanless, S. B., Murray, A., Saracho, O., \& Spodek, B. (2007). Executive function, behavioral self-regulation, and social-emotional competence. Contemporary Perspectives on Social Learning in Early Childhood Education, 1, 113-137.

McWayne, C. M., Fantuzzo, J. W., \& McDermott, P. A. (2004). Preschool competency in context: An investigation of the unique contribution of child competencies to early academic success. Developmental Psychology, 40, 633-645. https://doi.org/10.1037/0012-1649.40.4.633

Michel, E., Roethlisberger, M., Neuenschwander, R., \& Roebers, C. M. (2011). Development of cognitive skills in children with motor coordination impairments at 12-month follow-up. Child Neuropsychology, 17(2), 
151-172. https://doi.org/10.1080/09297049.2010.525501

Moffitt, T. E., Arseneault, L., Belsky, D., Dickson, N., Hancox, R. J., Harrington, H., ... \& Sears, M. R. (2011). A gradient of childhood self-control predicts health, wealth, and public safety. Proceedings of the National Academy of Sciences, 108(7), 2693-2698. https://doi.org/10.1073/pnas.1010076108

Montroy, J. J., Bowles, R. P., Skibbe, L. E., \& Foster, T. D. (2014). Social skills and problem behaviors as mediators of the relationship between behavioral self-regulation and academic achievement. Early Childhood Research Quarterly, 29(3), 298-309. https://doi.org/10.1016/j.ecresq.2014.03.002

Montroy, J. J., Bowles, R. P., Skibbe, L. E., McClelland, M. M., \& Morrison, F. J. (2016). The development of self-regulation across early childhood. Developmental Psychology, 52(11), 1744-1762. https://doi.org/10.1037/dev0000159

Naglieri, J. A., \& Kaufman, J. C. (2001). Understanding intelligence, giftedness and creativity using PASS theory. Roeper Review, 23, 151-156. https://doi.org/10.1080/02783190109554087

Nigg, J. T., Quamma, J. P., Greenberg, M. T., \& Kusché, C. A. (1999). A two-year longitudinal study of neuropsychological and cognitive performance in relation to behavioral problems and competencies in elementary school children. Journal of Abnormal Child Psychology, 27, 51-63. https://doi.org/10.1023/A:1022614407893

Pagani, L. S., Fitzpatrick, C., Archambault, I., \& Janosz, M. (2010). School readiness and later achievement: A French Canadian replication and extension. Developmental Psychology, 46, 984-994. https://doi.org/10.1037/a0018881

Piek, J. P., G. S. Bradbury, S. C. Elsley, and L. Tate. 2008a. Motor Coordination and Social-Emotional Behaviour in Preschool-Aged Children. International Journal of Disability, Development and Education, 55(2), 143-151. https://doi.org/10.1080/10349120802033592

Piek, J. P., L. Dawson, L. M. Smith, and N. Gasson. 2008b. The Role of Early Fine and Gross Motor Development on Later Motor and Cognitive Ability. Human Movement Science, 27(5), 668-681. https://doi.org/10.1016/j.humov.2007.11.002

Ponitz, C. C., McClelland, M. M., Matthews, J. S., \& Morrison, F. J. (2009). A structured observation of behavioral self-regulation and its contribution to kindergarten outcomes. Developmental psychology, 45(3), 605. https://doi.org/10.1037/a0015365

Pool, J. L., \& Hourcade, J. J. (2011). Developmental screening: A review of contemporary practice. Education and Training in Autism and Developmental Disabilities, 267-275.

Posner, M. I., \& Rothbart, M. K. (1998). Attention, self-regulation and consciousness. Philosophical Transactions of the Royal Society of London. Series B: Biological Sciences, 353(1377), 1915-1927. https://doi.org/10.1098/rstb.1998.0344

Posner, M. I., \& Rothbart, M. K. (2007). Research on attention networks as a model for the integration of $\begin{array}{llllll}\text { psychological } \quad \text { science. } & \text { Annu. }\end{array}$ https://doi.org/10.1146/annurev.psych.58.110405.085516

Reid, E. E., Diperna, J. C., Missall, K., \& Volpe, R. J. (2014). Reliability and structural validity of the teacher rating scales of early academic competence. Psychology in the Schools, 51(6), 535-553. https://doi.org/10.1002/pits.21769

Romero-Martínez, S. J., Ordóñez-Camacho, X. G., \& Gil-Madrona, P. (2018). Development of the Checklist of Psychomotor Activities for 5-to 6-Year-Old Children. Perceptual and Motor Skills, 125(6), 1070-1092. https://doi.org/10.1177/0031512518804359

Ross1, A. (2012). Considerations about the psychomotricity in children's Education. Valley Voices Magazine: academic publications. UFVJM, no 1, year 1, $18 \mathrm{p}$.

Rothbart, M. K., \& Bates, J. E. (2006). Temperament. In W. Damon, R. M. Lerner, \& N. Eisenberg (Eds.), Handbook of child psychology: Vol. 3. Social, emotional, and personality development (6th ed., pp. 99-166). New York, NY: Wiley.

Rothbart, M. K., Ahadi, S. A., Hershey, K. L., \& Fisher, P. (2001). Investigations of temperament at three to seven years: The Children's Behavior Questionnaire. Child Development, 72(5), 1394-1408. https://doi.org/10.1111/1467-8624.00355 
Şahin, G., \& Arı, R. (2017). Nesne Seçiminde Esneklik Görevi (N ESG): Geçerlik ve Güvenirlik Çalışması. Electronic Turkish Studies, 12(25), 721-736. https://doi.org/10.7827/TurkishStudies.12250

Sarnadinha, A., Pereira, C., Cruz-Ferreira, A., Fernandes, J., \& Veiga, G. (2018). Preschooler's executive and socio-emotional functioning: Effects of two intervention programs-Psychomotor therapy and Creative Dance. BMC Health Services Research, 18(Suppl 2), 684.

Scarborough, H. (2001). Connecting early language and literacy to later reading (dis)abilities: Evidence, theory and practice. In S. Neuman, \& D. Dickinson (Eds.), Handbook of emergent literacy research. NY: Guildford Press

Scibinetti, P., Tocci, N., \& Pesce, C. (2011). Motor creativity and creative thinking in children: The diverging role of inhibition. Creativity Research Journal, 23(3), 262-272. https://doi.org/10.1080/10400419.2011.595993

Sektnan, M., McClelland, M. M., Acock, A., \& Morrison, F. J. (2010). Relations between early family risk, children's behavioral regulation, and academic achievement. Early Childhood Research Quarterly, 25(4), 464-479. https://doi.org/10.1016/j.ecresq.2010.02.005

Şenol, F. B., \& Turan, F. (2019). Teacher Rating Scales of Early Academic Competence (TRS-EAC): Adaptation to Turkish, validity and reliability. International Journal of Educational Methodology, 5(1), 43-57. https://doi.org/10.12973/ijem.5.1.43

Sezgin, E., \& Demiriz, S. (2016). Çocuk davranış değerlendirme ölçeği'nin (çoddö) türkçe'ye uyarlanması: Geçerlik ve güvenirlik çalışması. Mersin Üniversitesi Eğitim Fakültesi Dergisi, 12(2), 702-718. https://doi.org/10.17860/efd.15303

Shaul, S., \& Schwartz, M. (2014). The role of the executive functions in school readiness among preschool-age children. Reading and Writing, 27(4), 749-768. https://doi.org/10.1007/s11145-013-9470-3

Suchodolets, A., Trommsdorff, G., Heikampa, T., Wieber, F., \& Gollwitzer, P. (2009). Transition to school: The role of kindergarten children's behavior regulation. Learning and Individual Differences, 1, 561-566. https://doi.org/10.1016/j.lindif.2009.07.006

Ursache, A., Blair, C., \& Raver, C. C. (2012). The promotion of self-regulation as a means of enhancing school readiness and early achievement in children at risk for school failure. Child Development Perspectives, 6(2), 122-128. https://doi.org/10.1111/j.1750-8606.2011.00209.x

Valiente, C., Eisenberg, N., Haugen, R. G., Spinrad, T. L., Hofer, C., Liew, J., \& Kupfer, A. (2011). Children's effortful control and academic achievement: Mediation through social functioning. Early Education \& Development, 22(3), 411-433. https://doi.org/10.1080/10409289.2010.505259

Valiente, C., Lemery-Chalfant, K., \& Swanson, J. (2010). Prediction of kindergartners' academic achievement from their effortful control and emotionality: Evidence for direct and moderated relations. Journal of Educational Psychology, 102(3), 550-560. https://doi.org/10.1037/a0018992

Valiente, C., Lemery-Chalfant, K., Swanson, J., \& Reiser, M. (2008). Prediction of children's academic competence from their effortful control, relationships, and classroom participation. Journal of educational psychology, 100(1), 67. https://doi.org/10.1037/0022-0663.100.1.67

Van den Broek, P., Lorch, E. P., \& Thurlow, R. (1996). Children's and adults' memory for television stories: The role of causal factors, story - grammar categories, and hierarchical level. Child Development, 67(6), 3010-3028. https://doi.org/10.1111/j.1467-8624.1996.tb01900.x

Vitiello, V. E., Greenfield, D. B., Munis, P., \& George, J. L. (2011). Cognitive flexibility, approaches to learning, and academic school readiness in Head Start preschool children. Early Education \& Development, 22(3), 388-410. https://doi.org/10.1080/10409289.2011.538366

Von Suchodoletz, A., Trommsdorff, G., Heikamp, T., Wieber, F., \& Gollwitzer, P. M. (2009). Transition to school: The role of kindergarten children's behavior regulation. Learning and Individual Differences, 19(4), 561-566. https://doi.org/10.1016/j.lindif.2009.07.006

Wanless, S. B., McClelland, M. M., Lan, X., Son, S. H., Cameron, C. E., Morrison, F. J., ... \& Sung, M. (2013). Gender differences in behavioral regulation in four societies: The United States, Taiwan, South Korea, and China. Early Childhood Research Quarterly, 28(3), 621-633. https://doi.org/10.1016/j.ecresq.2013.04.002

Wanless, S. B., McClelland, M. M., Tominey, S. L. ve Acock, A. C. (2011). The influence of demographic risk factors on children's behavioral regulation in prekindergarten and kindergarten. Early Education and 
Development, 22, 461-488. https://doi.org/10.1080/10409289.2011.536132

Wass, S. V., Scerif, G., \& Johnson, M. H. (2012). Training attentional control and working memory-Is younger, better?. Developmental Review, 32(4), 360-387. https://doi.org/10.1016/j.dr.2012.07.001

Wassenberg, R., Feron, F. J., Kessels, A. G., Hendriksen, J. G., Kalff, A. C., Kroes, M., ... \& Vles, J. S. (2005). Relation between cognitive and motor performance in 5 to 6 year old children: Results from a large-scale $\begin{array}{lllll}\text { cross-sectional } & \text { Child }\end{array}$ https://doi.org/10.1111/j.1467-8624.2005.00899.x

Welsh, J. A., Nix, R. L., Blair, C., Bierman, K. L., and Nelson, K. E. (2010). The development of cognitive skills and gains in academic school readiness for children from low-income families. J. Educ. Psychol., 102, 43-53. https://doi.org/10.1037/a0016738

Welsh, M., Parke, R. D., Widaman, K., \& O’Neil, R. (2001). Linkages between children's social and academic competence: A longitudinal analysis. Journal of School Psychology, 39(6), 463-482. https://doi.org/10.1016/S0022-4405(01)00084-X

Wentzel, K., Baker, S., \& Russell, S. (2009). Peer relationships and positive adjustment at school. Handbook of positive psychology in schools, 229-243.

Whitehurst, G. J., \& Lonigan, C. J. (1998). Child development and emergent literacy. Child development, 69(3), 848-872. https://doi.org/10.1111/j.1467-8624.1998.tb06247.x

Yalçıntaş-Sezgin, Ulus, L., \& Şahin, İ. (2019). The Examination of Relationship Between Behavioral Regulation with Phonological Awareness, Matching Images and Pre-Writing Skills in Preschool Children. Sakarya University Journal of Education, 9(1), 107-128. https://doi.org/10.19126/suje.463610

Zaragas, H. K., \& Pliogou, V. (2020). Assessment and pedagogical implications of young children's psychomotor development in Greek kindergarten schools. Education 3-13, 48(2), 239-251. https://doi.org/10.1080/03004279.2019.1684540

Zhang, L., \& Rao, N. (2017). Effortful control and academic achievement in rural China. Early Education and Development, 28(5), 541-558. https://doi.org/10.1080/10409289.2016.1255080

Zhou, Q., Chen, S. H., \& Main, A. (2012). Commonalities and differences in the research on children's effortful control and executive function: A call for an integrated model of self regulation. Child Development Perspectives, 6(2), 112-121. https://doi.org/10.1111/j.1750-8606.2011.00176.x

Zhou, Q., Hofer, C., Eisenberg, N., Reiser, M., Spinrad, T. L., \& Fabes, R. A. (2007). The developmental trajectories of attention focusing, attentional and behavioral persistence, and externalizing problems during school-age years. Developmental psychology, 43(2), 369. https://doi.org/10.1037/0012-1649.43.2.369

Zimmerman, B. J. (2000). Attaining self-regulation: A social cognitive perspective. In P. Pintrich, M. Boekaerts, \& M. Zeidner (Eds.), Handbook of self-regulation (pp. 13-39). Orlando, FL: Academic Press. https://doi.org/10.1016/B978-012109890-2/50031-7

\section{Copyrights}

Copyright for this article is retained by the author(s), with first publication rights granted to the journal.

This is an open-access article distributed under the terms and conditions of the Creative Commons Attribution license (http://creativecommons.org/licenses/by/4.0/). 